\title{
Demonstration of biological activities of extracts from Isodon rugosus Wall. Ex Benth: Separation and identification of bioactive phytoconstituents by GC-MS analysis in the ethyl acetate extract
}

\author{
Anwar Zeb, Farhat Ullah, Muhammad Ayaz, Sajjad Ahmad and Abdul Sadiq ${ }^{*}$
}

\begin{abstract}
Background: Since long, natural sources have been explored for possible managements of various diseases. In this context, the study is designed to evaluate Isodon rugosus Wall. ex Benth for biological potentials including antibacterial, anthelmintic, insecticidal, anti-termites and anti-Pharaoh activities followed by GC-MS analysis of active fraction to identify various bioactive compounds.

Methods: I. rugosus was investigated against eight bacterial strains using well diffusion method and microdilution method with ceftriaxone as positive control. Similarly, the insecticidal activity was carried out against Tribolium castaneum, Rhyzopertha dominica, Monomorium pharaonis and Heterotermis indicola following contact toxicity method. Likewise, anthelmintic activity was performed against Ascaridia galli and Pherethima posthuma using albendazole as positive control, in which the paralysis and death times of the worms were observed. The GC-MS analysis of the most active solvent fraction was performed for identifications of various bioactive compounds.

Results: Among the tested samples of I. rugosus, flavonoids and ethyl acetate fraction exhibited high antibacterial activities. The crude saponins showed highest anthelmintic activity against Pherethima posthuma and Ascaridia galli with death times of 27.67 and 29.22 min respectively at concentrations of $40 \mathrm{mg} / \mathrm{ml}$. In insecticidal activity, chloroform fraction and saponins exhibited notable results against $R$. dominica (60 and 70\%) and T. castaneum (70 and 76\%) at concentration of $200 \mathrm{mg} / \mathrm{ml}$. In anti-termite assay, all the plant samples showed overwhelming results, i.e. all the 25 termites were killed on the 3rd day. Similarly, in anti-Pharaoh activity, the chloroform, ethyl acetate and saponins fractions were most potent, each exhibiting $L_{50}$ of $<0.1 \mathrm{mg} / \mathrm{ml}$. In GC-MS analysis, total of 57 compounds were identified. Some of the bioactive compounds identified in GC-MS analysis are palmitic acid, hinokiol, a-amyrin, phytol, ethyl linolate, cyclohexanone, hinokione, methyl palmitate, ethyl palmitate and stigmasterol acetate.

Conclusions: Based on our current results, it can be concluded that I. rugosus possess strong antibacterial, insecticidal and anthelmintic potentials having crude saponins and ethyl acetate as the most active fractions. The GC-MS analysis and biological assays reveal that ethyl acetate fraction is a suitable target for the isolation of diverse array of bioactive compounds.
\end{abstract}

Keywords: Antibacterial, MICs, Anthelmintic, Ascaridia galli, Anti-termites, Anti-Pharaoh, Isodon rugosus, GC-ms

* Correspondence: sadiquom@yahoo.com

Department of Pharmacy, University of Malakand, Chakdara, Dir, KPK

(L)18000, Pakistan International License (http://creativecommons.org/licenses/by/4.0/), which permits unrestricted use, distribution, and reproduction in any medium, provided you give appropriate credit to the original author(s) and the source, provide a link to the Creative Commons license, and indicate if changes were made. The Creative Commons Public Domain Dedication waiver (http://creativecommons.org/publicdomain/zero/1.0/) applies to the data made available in this article, unless otherwise stated. 


\section{Background}

Infectious diseases are among the leading health problems, accounting for $41 \%$ of global disease burden [1]. Diseases caused by bacteria and parasites are still challenging to public health. Their impact is particularly large in developing countries due to unavailability of relevant medicines and the emergence of widespread drug resistance [2-4]. The clinical efficacy of many existing antibiotics has been endangered by the emergence of MDR pathogens [5, 6]. To triumph over MDR pathogens, it is important to develop novel and more effective antimicrobial agents, especially with a different mechanism of action [7]. It is obvious that despite synthetic compounds, natural raw materials are the key sources for novel therapeutic agents for the management of various ailments like infectious diseases $[8,9]$.

Helminthiasis is among the most widespread parasitic infections in humans, distressing an enormous population of the world. Approximately two billions people are suffering from parasitic worms infections [10]. Majority of helminths mediated infections are limited to tropical regions and cause huge hazard to health leading to undernourishment, anaemia, eosinophilia, physical, mental sluggishness and pneumonia [11]. Parasitic infections also cause lymphatic filariasis leading to elephantiasis, onchocerciasis called river blindness and schistosomiasis. These infections are more common in populations living in endemic areas with poor hygiene and socio-economic problems [12]. Livestock and crops are also affected by parasitic worms thus leading to reduction in crops and milk production [13]. There is a substantial improvement in helminths control but due to emergence of anthelmintic resistance to currently available drugs. So, it is important to search alternative strategies against gastrointestinal nematodes [14]. Similarly, most of the available insecticidal from chemical sources are hazardous to human health and are associated with environmental risks [15]. Therefore, alternative resources must be explored to substitute the chemical pesticides. Pesticides from natural sources are advantageous as they are selective in targeting specific species and also have unique modes of action [16].

Isodon rugosus Wall. ex Benth. belongs to the family Lamiaceae. Isodon, an important genus of this family is a rich source containing a large number of bioactive compounds. The Isodon species have been used as anti-tumor, anticancer, antimicrobial, insecticide and anthelmintic [17, 18]. Isodon rugosus has been used ethnomedicinally as an antimicrobial and anthelmintic $[19,20]$. This plant has also been used traditionally against skin infections and for the treatment of scabies [21, 22]. This specie has also been verified scientifically to possess variety of pharmacological activities [23]. Based on the published literature, the current study is designed to evaluate various fractions of $I$. rugosus for the antimicrobial, anthelmintic and insecticidal potentials along with identifications and sorting out of bioactive compounds by GC-MS analysis.

\section{Methods \\ Plant collection and extraction}

The plant was collected from Dir (KPK), Pakistan in the month of June and was identified by plant taxonomist at Department of Botany, Shaheed Benazir Bhuto University Dir (KPK), Pakistan. The plant sample was kept at the herbarium of the same university with voucher number 1016AZ. Fresh aerial parts $(11 \mathrm{~kg})$ were separated from the rest of the plant and rinsed with clean water to remove any dust particles followed by shade drying for 23 days. The dried plant parts were cut into small pieces and grinded into coarse powder with the help of a grinder. The powdered material $(6 \mathrm{~kg}$ ) was macerated in $80 \%$ methanol $(25 \mathrm{~L})$ for 18 days and the process was repeated three times. The filtrates were combined and concentrated under reduced pressure using rotary evaporator [24, 25]. A brown semisolid mass (380 g) of the crude methanolic extracts was obtained.

\section{Fractionation}

The crude methanolic extract was transferred into a separating funnel and diluted with $500 \mathrm{ml}$ of distilled water. $n$-Hexane $(500 \mathrm{ml})$ was added to it with vigorous shaking and kept for a while to form two layers. The $n$-hexane layer was separated and repeated the same procedure three times by adding $500 \mathrm{ml}$ of $n$-hexane each time. All the $n$-hexane layers were combined and concentrated at reduced pressure using rotary evaporator. The final concentrated weight of $n$-hexane fraction was $19 \mathrm{~g}$. In a similar way like $n$-hexane fraction, the chloroform and ethyl acetate fractions were extracted sequentially weighing 27 and $80 \mathrm{~g}$ respectively. The dry water residue (aqueous fraction) was collected at the end weighing $125 \mathrm{~g}[26,27]$.

\section{Extraction of crude saponins}

The crude saponins from I. rugosus were obtained by adding $20 \mathrm{~g}$ of the plant powder in a conical flask having $100 \mathrm{ml}$ of $20 \%$ ethanol. The sample was heated in water bath for $4 \mathrm{~h}$ at $55{ }^{\circ} \mathrm{C}$ with continuous stirring. The mixture was filtered and extracted again with $200 \mathrm{ml}$ of $20 \%$ ethanol. The volume was heated up to $60{ }^{\circ} \mathrm{C}$ in water bath and got $40 \mathrm{ml}$ of greenish color residue. The residue was added into the separating funnel followed by the addition of diethyl ether $(20 \mathrm{ml})$ with vigorous shaking. After vigorous shaking, the separating funnel was put in a stand to get two distinct layers. The upper diethyl ether layer was discarded while the lower aqueous layer obtained was diluted with $n$-butanol $(60 \mathrm{ml})$. This extract was washed with $10 \mathrm{ml}$ of $5 \%$ sodium 
chloride solution. The solution was evaporated by keeping in water bath to obtained the dried saponins [26].

\section{Extraction of Flavonoids}

Plant sample having weight of $20 \mathrm{~g}$ was heated at $50{ }^{\circ} \mathrm{C}$ in $200 \mathrm{ml}$ of $\mathrm{HCl}(2 \mathrm{M})$ under reflux for $30 \mathrm{~min}$. The plant sample was filtered using Whatman No. 42 filter paper after getting cold. The filtrate obtained was poured into a separating funnel and added equal volume of ethyl acetate. The total amount of flavonoids present in the plant sample was precipitated, which were collected from the sample using a filter paper. The weight of flavonoids was $1.4 \mathrm{~g}(7 \%)$ [28].

\section{Gas chromatography (GC) analysis}

Ethyl acetate fraction was subjected to GC analysis and the GCMS was done by means of an Agilent USB-393752 gas chromatograph (Agilent Technologies, Palo Alto, CA, USA) with HHP-5MS phenylmethylsiloxane 5\% with capillary column $(30 \mathrm{~m} \times 0.25 \mathrm{~mm} \times 0.25 \mu \mathrm{m}$; Restek, Bellefonte, PA) equipped with an FID detector. Initially, the temperature of oven was maintained at $70{ }^{\circ} \mathrm{C}$ for $1 \mathrm{~min}$, and then increased the required temperature slowly and step wise to $180{ }^{\circ} \mathrm{C}$ at the rate of $6{ }^{\circ} \mathrm{C} / \mathrm{min}$ for $5 \mathrm{~min}$, and at the final stage increased the temperature to $280{ }^{\circ} \mathrm{C}$ at the rate of $5{ }^{\circ} \mathrm{C} / \mathrm{min}$ for $20 \mathrm{~min}$. The temperatures of the Injector and detector were set at $220^{\circ} \mathrm{C}$ and $290^{\circ} \mathrm{C}$, respectively. Helium was used as a carrier gas with a flow rate of $1 \mathrm{ml} / \mathrm{min}$ [29].

Gas chromatography-mass spectrometry (GC/MS) analysis Ethyl acetate fraction was subjected to GC/MS analysis and the processed was done by means of an Agilent USB393752 gas chromatograph (Agilent Technologies, Palo Alto, CA, USA) with a HHP-5MS phenylmethylsiloxane $5 \%$ with a capillary column $(30 \mathrm{~m} \times 0.25 \mathrm{~mm} \times 0.25 \mu \mathrm{m}$ film thickness; Restek, Bellefonte, PA) prepared with an Agilent HP-5973 mass selective detector in the electron impact mode (ionization energy: $70 \mathrm{ev}$ ) working under similar experimental background as illustrated for GC.

\section{Identification of components}

Identification of the compounds present in the ethyl acetate fraction of I. rugosus was carried out on the base of comparison of their relative retention indices of each component with those of the authentic compounds present in the literature. Further identifications of the compounds were carried out from the spectral data obtained from the Wiley and NIST libraries and additional identifications were carried out by completed comparisons of the fragmentation pattern of the mass spectra with the reported in literature [30].

\section{Antibacterial investigations \\ Bacterial strains}

Eight bacterial strains including Escherichia coli (739), Klebsiella pneumoniae (700603), Pseudomonas aeruginosa (27853), Enterococcus faecalis (29212), Proteus mirabilis (13315), Staphylococcus aureus (29213), Bacillus cereus and Salmonella typhi were used to investigate antibacterial potential of plant's samples. The samples were provided by the Microbiology Laboratory of Department of Microbiology, Quaid-e-Azam University, Islamabad. Bacteria were preserved in freeze-dried condition at $4{ }^{\circ} \mathrm{C}$ in stab slant agar until later use.

\section{Preparation and standardization of inoculums}

Bacterial cultures were grown for $24 \mathrm{~h}$ at $37^{\circ} \mathrm{C}$ and suspensions with cell density of $1 \times 10^{8} \mathrm{CFU} / \mathrm{ml}$, were prepared using McFarland standard and was further diluted to a cell density of $1 \times 10^{6} \mathrm{CFU} / \mathrm{ml}$ using a UV visible spectrophotometer (Thermo electron corporation USA) at $625 \mathrm{~nm}$ and the standardization was maintained for the period of the study [31].

\section{Antibacterial assay}

Preliminary antibacterial activity of plant extracts were investigated using well assay technique [32, 33]. Briefly, Nutrient agar plates were prepared and inoculated with the test organisms aseptically under laminar flow hood and were properly labeled. Wells of $5 \mathrm{~mm}$ diameter were made in the plates using sterile cork borer. Samples were prepared having concentrations of $10 \mathrm{mg} / \mathrm{ml}$. From each sample, $100 \mu \mathrm{l}$ of extract was added into each well using micropipette. The standard drug ceftriaxone was used as positive control, which was added into the central well contained in nutrient agar media in each Petri plate. After inoculation and addition of the samples, the Petri plates were kept in incubator at $37^{\circ} \mathrm{C}$ for $24 \mathrm{~h}$. Diameter of inhibitory zones were determined around each bore after $24 \mathrm{~h}$ and were compared with positive control. Experiments were performed in triplicate and the data obtained was represented as mean \pm SEM.

\section{Determination of MICs}

MICs were determined using microdilution method as described by National Committee for Clinical Laboratory Standards (NCCLS) [34]. Briefly, the plant's samples were prepared at concentrations of $50 \mathrm{mg} / \mathrm{ml}$ (stock solution) in sterile distilled water and serially diluted with distilled water to $20,17.5,15,12.5,10,7.5,5,2.5,1$ and $0.5 \mu \mathrm{g} / \mathrm{ml}$ using nutrient broth followed by inoculation with $0.2 \mathrm{ml}$ suspension of the test organisms. After $24 \mathrm{~h}$ of incubation at $37{ }^{\circ} \mathrm{C}$, the test tubes were visually observed for growth. The lowest concentration at which no growth of the microorganism was observed was 
Table 1 List of all compounds identified in the GC-MS analysis of ethyl acetate fraction of Isodon rugosus

\begin{tabular}{|c|c|c|c|c|c|}
\hline S. No & Compound Label & RT & Name & Formula & Hits (DB) \\
\hline 1. & $\begin{array}{l}\text { Cyclohexanone (CAS) \$\$ Anon } \$ \$ \text { Anone } \$ \$ \text { Nadone } \$ \$ \\
\text { Hexanon } \$ \$ \text { Sextone }\end{array}$ & 3.858 & Cyclohexanone & $\mathrm{C} 6 \mathrm{H} 10 \mathrm{O}$ & 10 \\
\hline 2. & $\begin{array}{l}\text { Ethanol, 2-ethoxy-, acetate (CAS) \$\$2-Ethoxyethyl acetate } \$ \$ \\
\text { Oxitol acetate }\end{array}$ & 3.936 & Oxitol acetate & $\mathrm{C} 6 \mathrm{H} 12 \mathrm{O} 3$ & 10 \\
\hline 3. & Cyclopentane, 1,1,3,4-tetramethyl-, trans- (CAS) & 4.726 & $\mathrm{Nf}$ & $\mathrm{C} 9 \mathrm{H} 18$ & 10 \\
\hline 4. & 1-(4-Tosyloxybutyl)-3-(1-methoxy-1-methylethoxy)clopentene & 4.842 & $\mathrm{Nf}$ & $\mathrm{C} 2 \mathrm{OH} 30 \mathrm{OSS}$ & 1 \\
\hline 5. & $\begin{array}{l}\text { (1.alpha.,5.alpha.,6.alpha.,7.alpha.)-6,7-(Z,E)-Dipropenyl-3- } \\
\text { oxabicyclo[3.2.... }\end{array}$ & 5.428 & $\mathrm{Nf}$ & $\mathrm{C} 12 \mathrm{H} 18 \mathrm{O}$ & 6 \\
\hline 6. & $\begin{array}{l}\text { Butanedioic acid, ethyl methyl ester (CAS) \$\$ 1-Ethyl 4-methyl } \\
\text { succinate }\end{array}$ & 7.031 & $\mathrm{Nf}$ & $\mathrm{C} 7 \mathrm{H} 12 \mathrm{O} 4$ & 10 \\
\hline 7. & N-Butylpropargylamine & 7.156 & Butylpropargylamine & $\mathrm{C} 7 \mathrm{H} 13 \mathrm{~N}$ & 10 \\
\hline 8. & $\begin{array}{l}\text { 2-Cyclohexen-1-one, 3,5,5-trimethyl- (CAS) \$\$ 3,5,5-Trimethyl-2- } \\
\text { cyclohexenone }\end{array}$ & 7.366 & $\mathrm{Nf}$ & $\mathrm{C} 9 \mathrm{H} 14 \mathrm{O}$ & 10 \\
\hline 9. & Succinic acid, butyl ethyl ester & 8.151 & $\mathrm{Nf}$ & $\mathrm{C} 10 \mathrm{H} 18 \mathrm{O} 4$ & 10 \\
\hline 10. & $\begin{array}{l}\text { Butanedioic acid (CAS) \$\$ Succinic acid (CAS) \$\$ Asuccin } \$ \$ \\
\text { Amber acid }\end{array}$ & 8.234 & Amber acid & $\mathrm{C} 4 \mathrm{H} 6 \mathrm{O} 4$ & 10 \\
\hline 11. & $\begin{array}{l}\text { Undecane, 4-methyl- (CAS) \$\$ 4-Methylundecane \$\$ } 4 \text { - } \\
\text { methyl - undecane }\end{array}$ & 8.456 & $\mathrm{Nf}$ & $\mathrm{C} 12 \mathrm{H} 26$ & 10 \\
\hline 12. & 1-(1,1-dimethyl-2-propenyl)-1-cyclohexene & 10.256 & $\mathrm{Nf}$ & $\mathrm{C} 11 \mathrm{H} 18$ & 10 \\
\hline 13. & $\begin{array}{l}\text { Dodecane, 2-methyl- (CAS) \$\$2-Methyldodecane \$\$ } \\
\text { 11-Methyldodecane }\end{array}$ & 11.258 & $\mathrm{Nf}$ & $\mathrm{C} 13 \mathrm{H} 28$ & 10 \\
\hline 14. & (+)-(E)-N,N-Di-tert-butoxycarbonyl-1,3-diphenylprop-2-enyamine & 12.008 & $\mathrm{Nf}$ & $\mathrm{C} 25 \mathrm{H} 31 \mathrm{NO} 4$ & 1 \\
\hline 15. & $\begin{array}{l}\text { Benzene, 1-(bromomethyl)-3-nitro- } \$ \$ \text { m-(Bromomethyl) } \\
\text { nitrobenzene }\end{array}$ & 12.284 & $\mathrm{Nf}$ & $\mathrm{C} 7 \mathrm{H} 6 \mathrm{BrNO} 2$ & 10 \\
\hline 16. & rac-gamma.(2)-muurolene & 12.418 & rac- $\gamma(2)$-muurolene & $\mathrm{C} 16 \mathrm{H} 24$ & 10 \\
\hline 17. & Decane, 3-bromo- \$\$3-Bromodecane \# & 12.54 & $\mathrm{Nf}$ & $\mathrm{C} 10 \mathrm{H} 21 \mathrm{Br}$ & 1 \\
\hline 18. & Acetic Acid 2-(4-Hydroxyphenyl)ethyl Ester & 13.523 & $\mathrm{Nf}$ & $\mathrm{C} 10 \mathrm{H} 12 \mathrm{O} 3$ & 10 \\
\hline 19. & Tetradecane, 1-chloro- $\$ \$$ Myristyl chloride $\$ \$$ Tetradecyl chloride & 13.738 & Myristyl chloride & $\mathrm{C} 14 \mathrm{H} 29 \mathrm{Cl}$ & 10 \\
\hline 20. & $\begin{array}{l}\text { alpha.-Amorphene \$\$. ALPHA. AMORPHENE \$ 6.alpha.-Cadina- } \\
\text { 4,9-diene, }(-) \text { - }\end{array}$ & 14.153 & a-Amorphene & $\mathrm{C} 15 \mathrm{H} 24$ & 10 \\
\hline 21. & $\begin{array}{l}\text { alpha.-Copaene } \$ \text { Copaene (CAS) \$ Copaen \$ (-)-alpha.- } \\
\text { Copaene }\end{array}$ & 14.516 & Copaen & $\mathrm{C} 15 \mathrm{H} 24$ & 10 \\
\hline 22. & $\begin{array}{l}\text { alpha.-Cadinol \$\$ Cadin-4-en-10-ol \$\$ 1-.alpha-Cadinol \$\$ 10-. } \\
\text { ALPHA.-CADINOL }\end{array}$ & 14.64 & a-Cadinol & $\mathrm{C} 15 \mathrm{H} 26 \mathrm{O}$ & 10 \\
\hline 23. & 4-((1E)-3-Hydroxy-1-propenyl)-2-methoxyphenol & 15.859 & $\mathrm{Nf}$ & $\mathrm{C} 10 \mathrm{H} 12 \mathrm{O} 3$ & 10 \\
\hline 24. & $\begin{array}{l}\text { (-)-Loliolide \$ } \$ \text { Loliolide } \$ \text { \$ Loliolid \$\$ Digiprolactone } \$ \$ \\
\text { Calendin }\end{array}$ & 16.428 & Loliolide & $\mathrm{C} 11 \mathrm{H} 16 \mathrm{O} 3$ & 2 \\
\hline 25. & $\begin{array}{l}\text { Neophytadiene } \$ \$ 7,11,15-T R I M E T H Y L, 3-M E T H Y L E N E-1- \\
\text { HEXADECENE }\end{array}$ & 17.314 & Neophytadiene & $\mathrm{C} 2 \mathrm{OH} 38$ & 10 \\
\hline 26. & $\begin{array}{l}\text { R-7-endo-p-phenylbenzoyloxy-6-anti-(.beta.-phenylethenyl)-2- } \\
\text { oxa-bicyclo[3.3.... }\end{array}$ & 17.447 & $\mathrm{Nf}$ & $\mathrm{C} 27 \mathrm{H} 24 \mathrm{O} 3$ & 1 \\
\hline 27. & 2-Hexadecen-1-ol, 3,7,11,15-tetramethyl-, [R-[R*, $R^{*}$-(E)]]- (CAS) & 18.25 & $\mathrm{Nf}$ & $\mathrm{C} 2 \mathrm{OH} 40 \mathrm{O}$ & 10 \\
\hline 28. & $\begin{array}{l}\text { Hexadecanoic acid, methyl ester (CAS) } \$ \$ \text { Methyl palmitate } \$ \$ \\
\text { Uniphat A60 }\end{array}$ & 19.316 & Methyl palmitate & $\mathrm{C} 17 \mathrm{H} 34 \mathrm{O} 2$ & 10 \\
\hline 29. & $\begin{array}{l}\mathrm{n} \text {-Hexadecanoic acid } \$ \$ \text { Hexadecanoic acid } \$ \text { n-Hexadecoic } \\
\text { acid } \$ \$ \text { Palmitic acid }\end{array}$ & 20.498 & Palmitic acid & $\mathrm{C} 16 \mathrm{H} 32 \mathrm{O} 2$ & 10 \\
\hline 30. & $\begin{array}{l}\text { Hexadecanoic acid, ethyl ester (CAS) \$\$ Ethyl palmitate } \$ \$ \\
\text { Ethyl hexadecanoate }\end{array}$ & 21.386 & Ethyl palmitate & $\mathrm{C} 18 \mathrm{H} 36 \mathrm{O} 2$ & 10 \\
\hline 31. & CIS-11,14,17-EICOSATRIENOIC ACID ME & 25.548 & $\mathrm{Nf}$ & $\mathrm{C} 21 \mathrm{H} 36 \mathrm{O} 2$ & 10 \\
\hline 32. & $\begin{array}{l}\text { Phytol \$\$ 2-Hexadecen-1-ol, 3,7,11,15-tetramethyl-, } \\
{\left[\mathrm{R}-\left[\mathrm{R}^{*}, \mathrm{R}^{*}-(\mathrm{E})\right]\right]-}\end{array}$ & 26.041 & Phytol & $\mathrm{C} 2 \mathrm{OH} 40 \mathrm{O}$ & 10 \\
\hline
\end{tabular}


Table 1 List of all compounds identified in the GC-MS analysis of ethyl acetate fraction of Isodon rugosus (Continued)

\begin{tabular}{|c|c|c|c|c|c|}
\hline 33. & 17-Octadecynoic acid & 27.132 & $\mathrm{Nf}$ & $\mathrm{C} 18 \mathrm{H} 32 \mathrm{O} 2$ & 10 \\
\hline 34. & $\begin{array}{l}\text { Linoleic acid ethyl ester } \$ \$ \text { Ethyl linoleate } \$ \$ \text { Ethyl linolate } \$ \$ \\
\text { Mandenol }\end{array}$ & 27.616 & Mandenol & $\mathrm{C} 2 \mathrm{OH} 36 \mathrm{O} 2$ & 10 \\
\hline 35. & $\begin{array}{l}\text { Acetic acid, chloro-, hexadecyl ester } \$ \$ \text { Chloro-acetic acid } \\
\text { hexadecyl ester }\end{array}$ & 27.817 & $\mathrm{Nf}$ & $\mathrm{C} 18 \mathrm{H} 35 \mathrm{ClO} 2$ & 10 \\
\hline 36. & $\begin{array}{l}\text { 9,12,15-Octadecatrienoic acid, methyl ester, (Z,Z,Z)- \$\$ Methyl } \\
\text { linolenate }\end{array}$ & 27.831 & Methyl linolenate & $\mathrm{C} 19 \mathrm{H} 32 \mathrm{O} 2$ & 10 \\
\hline 37. & $\begin{array}{l}\text { Octadecanoic acid, ethyl ester (CAS) } \$ \$ \text { Ethyl stearate } \$ \$ \text { Ethyl } \\
\text { octadecanoate }\end{array}$ & 28.617 & Ethyl stearate & $\mathrm{C} 2 \mathrm{OH} 40 \mathrm{O} 2$ & 10 \\
\hline 38. & $\begin{array}{l}\text { Neophytadiene } \$ \$ 7,11,15-\text { TRIMETHYL,3-METHYLENE-1- } \\
\text { HEXADECENE }\end{array}$ & 29.321 & Neophytadiene & $\mathrm{C} 2 \mathrm{OH} 38$ & 10 \\
\hline 39. & $\begin{array}{l}\text { Hexadecanoic acid, ethyl ester (CAS) \$\$ Ethyl palmitate } \$ \$ \\
\text { Ethyl hexadecanoate }\end{array}$ & 33.473 & Ethyl palmitate & $\mathrm{C} 18 \mathrm{H} 36 \mathrm{O} 2$ & 10 \\
\hline 40. & $\begin{array}{l}\text { Naphthalene, 1,2,3,4-tetrahydro-1-isopropyl-1,2,4,4,7- } \\
\text { pentamethyl- }\end{array}$ & 35.4 & $\mathrm{Nf}$ & $\mathrm{C} 18 \mathrm{H} 28$ & 1 \\
\hline 41. & $\begin{array}{l}\text { 3,4,8-trimethyl-9-oxy-1-trimethylsilyloxybicyclo[4.3.1] } \\
\text { non-1-ene }\end{array}$ & 35.883 & $\mathrm{Nf}$ & $\mathrm{C} 15 \mathrm{H} 26 \mathrm{O} 2 \mathrm{Si}$ & 10 \\
\hline 42. & $\begin{array}{l}\text { Di-(2-ethylhexyl)phthalate } \$ \$ 1,2-B E N Z E N E D I C A R B O X Y L I C \\
\text { ACID }\end{array}$ & 36.417 & $\mathrm{Nf}$ & $\mathrm{C} 24 \mathrm{H} 38 \mathrm{O} 4$ & 10 \\
\hline 43. & Hinokione \$\$ (+)-Hinokione & 36.604 & Hinokione & $\mathrm{C} 2 \mathrm{OH} 28 \mathrm{O} 2$ & 10 \\
\hline 44. & $\begin{array}{l}{[1,3,4] \text { thiadiazolo[3,2-a]pyrimidin-7-one, 6- }} \\
\text { (2,5-dimethoxybenzylidene)-5-imi... }\end{array}$ & 37.056 & $\mathrm{Nf}$ & $\mathrm{C} 15 \mathrm{H} 14 \mathrm{~N} 4 \mathrm{O} 3 \mathrm{~S}$ & 1 \\
\hline 45. & Hinokiol \$\$ (+)-Hinokiol & 37.242 & Hinokiol & $\mathrm{C} 2 \mathrm{OH} 30 \mathrm{O} 2$ & 4 \\
\hline 46. & 7,8,9-Trimethoxy-4,5-dihydro-1H-benzo[g]indazole & 39.446 & $\mathrm{Nf}$ & $\mathrm{C} 14 \mathrm{H} 16 \mathrm{~N} 2 \mathrm{O} 3$ & 1 \\
\hline 47. & $\begin{array}{l}\text { 13b-methyl-3-propyl-1,3,4,6,7,8,13,13b-octahydro-2 h-pyrido } \\
{\left[1^{\prime}, 2: 1,1 \text {, ]azepino... }\right.}\end{array}$ & 40.14 & $\mathrm{Nf}$ & $\mathrm{C} 2 \mathrm{OH} 28 \mathrm{~N} 2$ & 10 \\
\hline 48. & 7,7-Dimethyl-6,7-diihydro-5H-benzo[f]pyrano[2,3-h]quinoxaline & 40.607 & $\mathrm{Nf}$ & $\mathrm{C} 17 \mathrm{H} 16 \mathrm{~N} 2 \mathrm{O}$ & 2 \\
\hline 49. & $\begin{array}{l}\text { 3-[(3,4-dimethoxy-benzylamino)-methyl]-8a-methyl-5-methylene- } \\
\text { decahydro-napht... }\end{array}$ & 40.934 & $\mathrm{Nf}$ & $\mathrm{C} 24 \mathrm{H} 33 \mathrm{NO} 4$ & 1 \\
\hline 50. & $\begin{array}{l}\text { 1-Hexadecanol (CAS) \$\$ Cetal \$\$ Ethal \$\$ Ethol \$\$ Cetanol \$\$ } \\
\text { Cetylol \$ Adol } 52\end{array}$ & 43.494 & Cetylol & $\mathrm{C} 16 \mathrm{H} 34 \mathrm{O}$ & 10 \\
\hline 51. & dl-.alpha.-Tocopherol \$ (.+/-.)-.alpha.-Tocopherol \$\$Vitamin E & 45.326 & Vitamin $\mathrm{E}$ & $\mathrm{C} 29 \mathrm{H} 50 \mathrm{O} 2$ & 7 \\
\hline 52. & 1,3-Diethyladamantane & 49.926 & $\mathrm{Nf}$ & $\mathrm{C} 14 \mathrm{H} 24$ & 2 \\
\hline 53. & $\begin{array}{l}\text { Stigmasta-5,22-dien-3-ol, acetate, (3.beta.)- } \$ \$ \text { Stigmasterol } \\
\text { acetate }\end{array}$ & 50.163 & Stigmasterol acetate & $\mathrm{C} 31 \mathrm{H} 50 \mathrm{O} 2$ & 6 \\
\hline 54. & $\begin{array}{l}\text { Viminalol \$\$ Urs-12-en-3-ol, (3.beta.)- (CAS) \$\$ .alpha.-Amyrin \$\$ } \\
\text { ALPHA-AMYRIN }\end{array}$ & 50.299 & Viminalol & $\mathrm{C} 30 \mathrm{H} 50 \mathrm{O}$ & 10 \\
\hline 55. & 4,6-Dimethoxy-2,3-diphenyl-7-(1-pyrrolin-2-yl)indole & 51.53 & $\mathrm{Nf}$ & $\mathrm{C} 26 \mathrm{H} 24 \mathrm{~N} 2 \mathrm{O} 2$ & 3 \\
\hline 56. & Stigmast-4-en-3-one \$\$ 4-Stigmasten-3-one $\$ \$$ Sitostenone & 51.622 & Sitostenone & $\mathrm{C} 29 \mathrm{H} 48 \mathrm{O}$ & 1 \\
\hline 57. & 4-Hydroxy-1,2-dimethoxyanthraquinone & 62.475 & $\mathrm{Nf}$ & $\mathrm{C} 16 \mathrm{H} 12 \mathrm{O} 5$ & 3 \\
\hline
\end{tabular}

considered as MIC of the plant extract against the relevant strains of the microorganisms.

\section{Anthelmintic investigations}

For the anthelmintic activity of I. rugosus, adult earthworms (Pherethima posthuma) and roundworms (Ascaridia galli) were used. Earthworms having average length of 7-8 cm and width $0.1-0.2 \mathrm{~cm}$ were collected from the muddy soil near Department of Pharmacy, University of Malakand, KPK, Pakistan. The selection of earthworms (P. posthuma) is based on close physiologic and anatomic resemblance with the human intestinal round worm parasites Ascaris lumbricoides [35]. Roundworms were collected from the intestines of chicken. The chickens were slaughtered, their intestines were dissected after the removal of fecal material with the help of normal saline and roundworms were collected from their intestines. These roundworms (A. galli) have close resemblance with that of the roundworm parasite (Ascaris lumbricoides) found in the human intestine. Both types of worms were divided into different groups, 
each group containing six (6) worms. All the extracts, their fractions, crude saponins and albendazole solutions were prepared in 10, 20 and $40 \mathrm{mg} / \mathrm{ml}$. From each solution, $25 \mathrm{ml}$ of the sample was transferred to sterilized Petri dishes $(150 \times 15 \mathrm{~mm})$ followed by addition of earthworms using forceps. Observations were made for the time taken when the worms lost their motility as paralysis time and death was concluded when no movement was observed even with vigorous shaking in hot water at $50{ }^{\circ} \mathrm{C}$. Both paralysis and death times were recorded for different fractions and were compared with the positive control [36].

\section{Insecticidal investigations \\ Anti-beetle}

The anti-beetle activity was carried out against $R$. dominica (grain borer) and T. castaneum (flour beetle) following the procedure previously described [37]. Various dilutions of extracts were prepared in methanol, i.e., 200, 100 and $50 \mathrm{mg} / \mathrm{ml}$ and filter paper was wetted with the $5 \mathrm{ml}$ of each test sample solution in Petri dishes and kept overnight to evaporate the solvent. After evaporation of the solvents, 20 healthy insects were shifted to each Petri dish and kept for $24 \mathrm{~h}$ at room temperature with $50 \%$ of relative humidity. After $24 \mathrm{~h}$, the results were checked by counting the number of dead and alive insects. Permethrin was used as positive control while the volatile solvents were used as negative control.

\section{Anti-termite investigations}

The anti-termite activity of crude saponins, methanolic extracts and resultant fractions of I. rugosus was conducted following standard procedure [38]. In this procedure the plant's samples were assayed against Heterotermes indicola (termites). Sterilized filter papers were kept in Petri dishes equal to the size of the Petri dishes. Samples were prepared by dissolving $2 \mathrm{mg} / \mathrm{ml}$ of each extract of the plant in respective solvents. The filter papers were kept for $24 \mathrm{~h}$ so that the solvents become fully evaporated from it. Each filter paper was kept in the labeled Petri dishes. In each Petri dish, 25 termites were placed and were kept for $24 \mathrm{~h}$ at room temperature. After $24 \mathrm{~h}$, the number of dead and alive termites was counted. Similarly, the results were also recorded on the second and third day. This activity was performed in triplicate and the average termites killed each day were recorded. Permethrin was used as positive control. The $\mathrm{LD}_{50}$ of each sample was calculated by graph prism pad software and Microsoft Excel.

\section{Anti-Pharaoh (ants) investigations}

The anti-Pharaoh activity was performed by the direct contact toxicity method described by Ahn et al. [37]. From each fraction, solutions of $0.5,1,2,4,6$ and $8 \mathrm{mg} /$ $\mathrm{ml}$ concentrations were prepared. Each concentration was added into Petri dish containing sterilized filter paper and kept for 12-15 h for evaporation of the solvent. After evaporation, 20 Pharaoh ants were added into each Petri dish. The Petri dishes containing distilled water treated filter paper served as a control. The Petri dishes were placed at room temperature for $24 \mathrm{~h}$ and numbers of dead and alive ants were observed in each Petri dish. Permethrin was used as positive control. The percent mortality of each sample was calculated and was compared with the positive control.

\section{Statistical analysis}

Each experiment was performed in three replicates and values were expressed as mean \pm SEM. two way ANOVA followed by multiple comparison Bonferroni's test. The $P$ values less than 0.05 were considered as statistically significant. $\mathrm{LD}_{50}$ values were calculated by a linear regression analysis among the percent inhibition against the extract concentrations via Excel program and GraphPad Prism software.

\section{Results}

Gas chromatography mass spectroscopy

The GC-MS analysis of ethyl acetate fraction revealed the identifications of 57 compounds which have been

Table 2 Various parameters major compounds in GC-MS of ethyl acetate fraction of Isodon rugosus

\begin{tabular}{|c|c|c|c|c|c|c|c|c|}
\hline S.No & RT & Height & Height \% & Area & Area \% & Area Sum \% & Base Peak m/z & Width \\
\hline 1. & 3.857 & 54,336 & 6.81 & 66,940 & 1.91 & 0.65 & 55.1 & 0.05 \\
\hline 2. & 3.938 & 57,317 & 7.19 & 70,955 & 2.03 & 0.69 & 43.1 & 0.054 \\
\hline 3. & 7.029 & 40,590 & 5.09 & 80,194 & 2.29 & 0.78 & 115 & 0.07 \\
\hline 4. & 7.367 & 581,648 & 72.95 & $1 E+06$ & 29.17 & 9.92 & 82 & 0.107 \\
\hline 5. & 8.15 & 74,641 & 9.36 & 122,166 & 3.49 & 1.19 & 101 & 0.054 \\
\hline 6. & 9.698 & 44,503 & 5.58 & 70,074 & 2 & 0.68 & 70.1 & 0.06 \\
\hline 7. & 11.73 & 62,937 & 7.89 & 90,543 & 2.59 & 0.88 & 93 & 0.05 \\
\hline 8. & 21.386 & 542,089 & 67.99 & $2 E+06$ & 66.56 & 22.64 & 88 & 0.171 \\
\hline 9. & 27.829 & 797,352 & 100 & $3 E+06$ & 100 & 34.02 & 79 & 0.178 \\
\hline 10. & 29.319 & 754,398 & 94.61 & $3 E+06$ & 78.36 & 26.66 & 68.1 & 0.137 \\
\hline
\end{tabular}




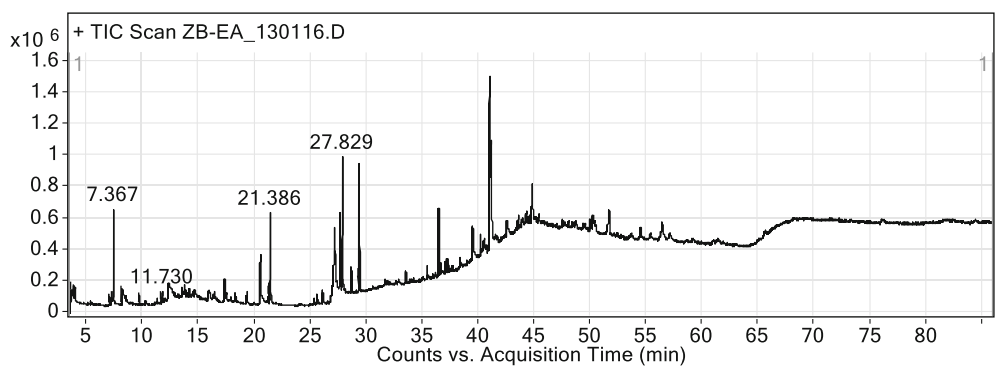

Fig. 1 Chromatogram of Ethyl acetate fraction of Isodon rugosus

enlisted in Table 1. Various parameters of major compounds in this fractions i.e., retention time, percent area, base peak, width etc. has also been summarized in Table 2. The GC-MS chromatogram of ethyl acetate fraction (Fig. 1) showed the peak areas for various compounds including the bioactive compounds. The structures of the bioactive compounds are shown in Fig. 2. The integration pattern of dominant compounds determined by GC-MS analysis is provided in Fig. 3.

\section{Antibacterial studies}

\section{Sensitivity pattern}

The bacterial strains were exposed to different antibiotic groups to determine their susceptibility pattern as shown in Table 3. All strains were found resistant to more than three antibiotics and therefore were termed as multi drug resistant (MDR) strains.

\section{Zone of inhibitions}

Results of antibacterial activity (ZOI) are shown in Table 4. Among all the tested samples, flavonoids were most active against all the strains and its antibacterial potential was comparable to the standard drug ceftriaxone. Among other fractions, ethyl acetate was most effective against $S$. aureus and S. typhi displaying inhibitory zones of $29.3 \pm 0.28$ and $28.2 \pm 0.35 \mathrm{~mm}$ respectively. Crude saponins were also effective against $S$. aureus, E. coli, B. cereus and $K$. pneumoniae causing inhibitory zones of $27.2 \pm 0.23, \quad 24.1 \pm 0.52,26.3 \pm 0.34$ and $21.3 \pm 0.39 \mathrm{~mm}$ respectively. The crude methanolic extract and chloroform fraction were inactive against $B$. cereus, whereas the aqueous fraction was inactive against $E$. coli and $E$. faecalis. $n$-Hexane fraction was also inactive against $E$. coli. All the test samples were approximately least active against $E$. coli.

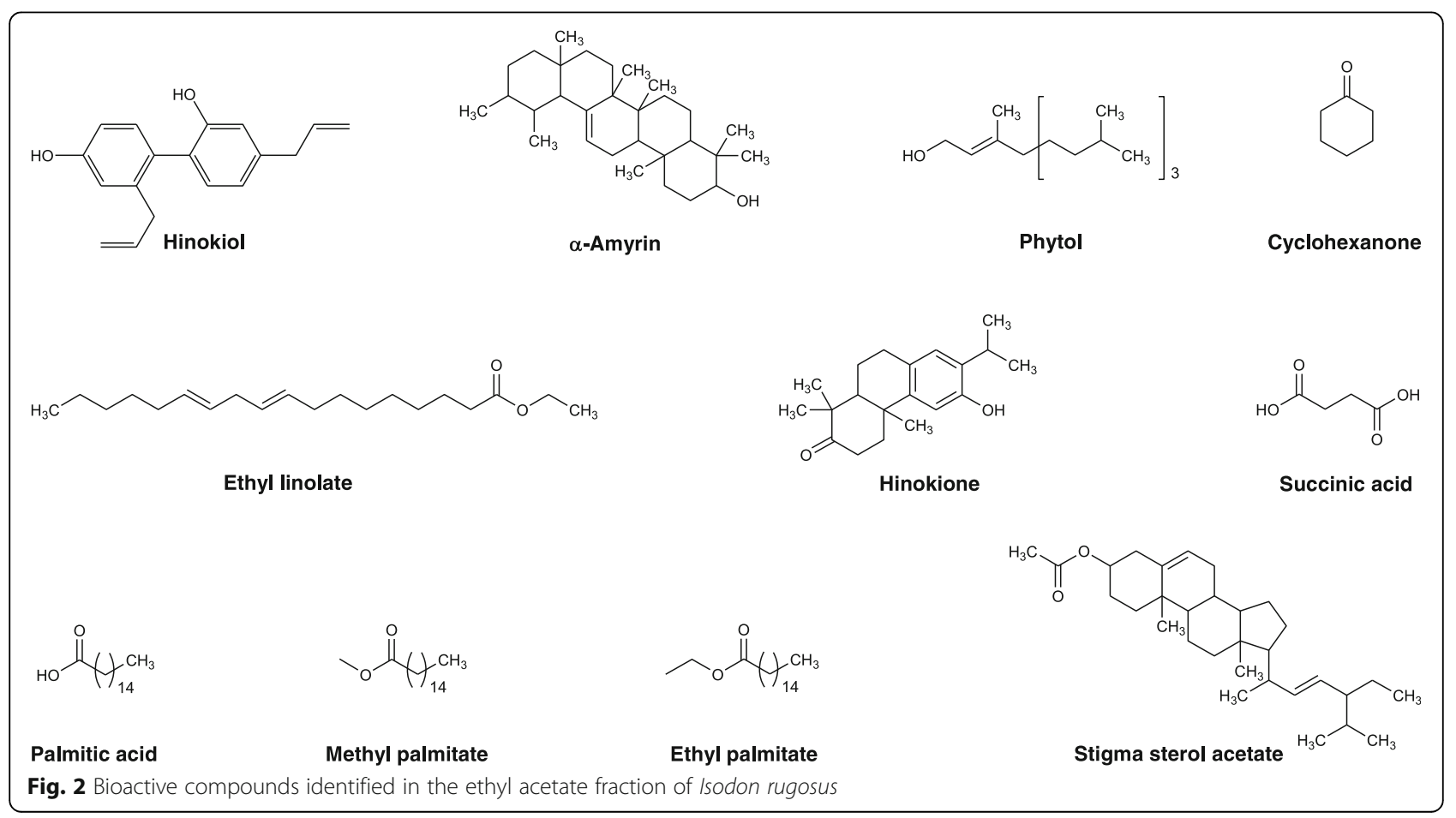



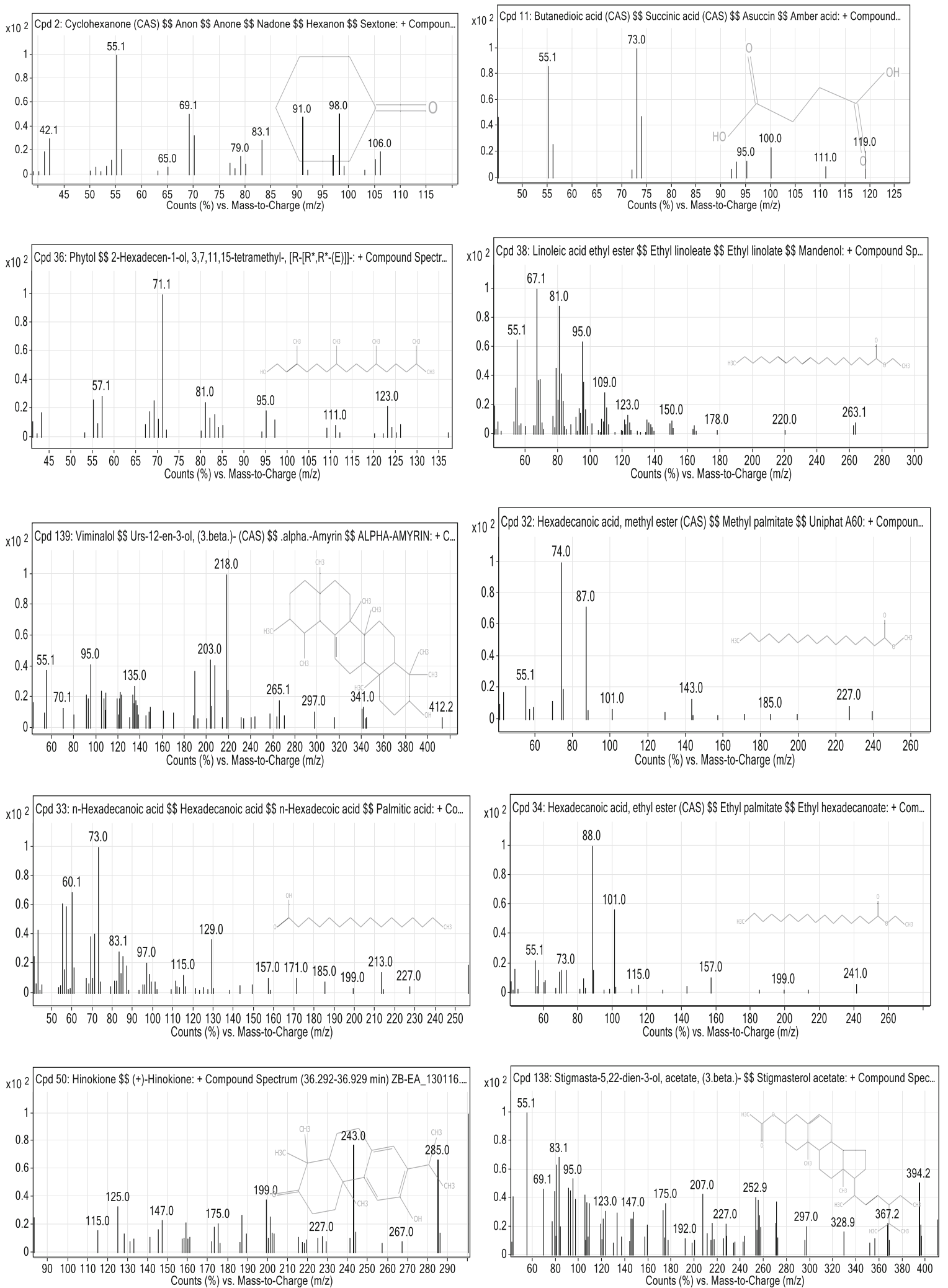

Fig. 3 Mass spectra of bioactive compounds in ethyl acetate fraction of Isodon rugosus 
Table 3 Antibiotic Susceptibility pattern of selected bacterial strains to different antibiotic groups

\begin{tabular}{|c|c|c|c|c|c|c|}
\hline \multirow[t]{2}{*}{ Bacterial strains } & \multicolumn{6}{|c|}{ Diameter of the inhibitory zone $(\mathrm{mm})$ Mean \pm SEM $(n=5)$} \\
\hline & Ciprofloxacin & Cefixime & Amoxycillin & Gentamycin & Cephradine & Cloxacillin \\
\hline Escherichia coli (739) & $24.67 \pm 1.20$ & $18.33 \pm 0.88$ & $07.67 \pm 0.67$ & $26.67 \pm 0.67$ & $06.67 \pm 0.88$ & $09.33 \pm 0.33$ \\
\hline Klebsiella pneumoniae (700603) & $19.00 \pm 0.57$ & $06.67 \pm 0.67$ & $08.00 \pm 0.57$ & $22.00 \pm 0.57$ & $08.67 \pm 0.88$ & $06.67 \pm 1.20$ \\
\hline Pseudomonas aeruginosa (27853) & $22.33 \pm 0.88$ & $16.67 \pm 1.20$ & $07.67 \pm 1.20$ & $20.67 \pm 1.20$ & $10.33 \pm 1.45$ & $08.33 \pm 0.33$ \\
\hline Enterococcus faecalis (29212) & $16.33 \pm 0.33$ & $12.33 \pm 0.88$ & $09.33 \pm 0.88$ & $26.67 \pm 0.67$ & $14.00 \pm 1.15$ & $06.67 \pm 0.67$ \\
\hline Proteus mirabilis (13315) & $18.67 \pm 1.20$ & $06.67 \pm 0.33$ & $10.67 \pm 0.33$ & $27.33 \pm 0.88$ & $10.00 \pm 0.57$ & $12.33 \pm 0.88$ \\
\hline Staphylococcus aureus (29213) & $26.67 \pm 0.67$ & $08.33 \pm 0.33$ & $14.00 \pm 0.57$ & $29.00 \pm 0.57$ & $12.33 \pm 0.88$ & $08.00 \pm 0.57$ \\
\hline Bacillus cereus & $23.00 \pm 0.57$ & $11.67 \pm 0.67$ & $11.33 \pm 0.88$ & $26.00 \pm 1.15$ & $12.67 \pm 0.67$ & $09.67 \pm 1.20$ \\
\hline Salmonella typhi & $23.33 \pm 0.33$ & $26.67 \pm 1.20$ & $7.67 \pm 1.20$ & $24.33 \pm 0.33$ & $10.00 \pm 1.15$ & $07.00 \pm 1.15$ \\
\hline
\end{tabular}

\section{Minimum inhibitory concentration (MICs)}

Among all the tested samples, crude methanolic extract was found most effective against $S$. aureus and B. cereus with minimum inhibitory concentrations (MICs) of $2.50 \pm 0.00$ and $2.66 \pm 1.30 \mu \mathrm{g} / \mathrm{ml}$. MIC of $n$-hexane fraction against $B$. cereus was $1.33 \pm 0.60 \mu \mathrm{g} / \mathrm{ml}$ which was comparable to positive control ceftriaxone displaying $\mathrm{MIC}$ of $0.83 \pm 0.16 \mu \mathrm{g} / \mathrm{ml}$. The chloroform fraction was most effective against $K$. pneumonia and E. coli, whose visible growth was inhibited at $1.16 \pm 0.66$ and $1.00 \pm 0.00 \mu \mathrm{g} / \mathrm{ml}$ respectively. Saponins fraction was most potent against $P$. mirabilis, S. aureus and $K$. pneumonia with MICs of $1.00 \pm 0.00,0.83 \pm 0.16$ and $1.00 \pm 0.00 \mu \mathrm{g} / \mathrm{ml}$ respectively. Flavonoids were also found equally effective against the tested microbes. All the results of minimum inhibitory concentrations (MICs) are summarized in Table 5.

\section{Anthelmintic activity}

All the tested fractions were effective in concentration dependent manner as shown in Table 6. The saponins fraction was observed to be most effective against Pheretima posthuma with an average death time of $44.00 \pm 2.00,33.67 \pm 3.05$ and $27.67 \pm 1.53 \mathrm{~min}$ at concentrations of $10,20,40 \mathrm{mg} / \mathrm{ml}$ respectively. The anthelmintic activity observed for saponins and chloroform fractions were comparable to the positive control albendazole. The order of anthelmintic activity for various fractions of the plant against Pheretima posthuma was in an ascending order of saponins $>$ chloroform $>$ ethyl acetate $>n$-hexane $>$ methanolic extract $>$ aqueous fraction. Moreover, crude saponins exhibited a significant result against Ascaridia galli with an average death time of $29.22 \pm 0.61 \mathrm{~min}$ at $40 \mathrm{mg} / \mathrm{ml}$ concentration. Whereas, average death time for the standard drug albendazole was $33.6 \pm 1.76$ at the same tested concentration.

\section{Insecticidal activity}

In finding out the insecticidal potentials of different fractions, saponins caused mortality to a significant level, i.e. $70.67 \pm 1.20$ and $76.65 \pm 1.65 \%$ mortality against $R$. dominica and T. castaneum respectively at a concentration of $200 \mathrm{mg} / \mathrm{ml}$, while at a concentration of $50 \mathrm{mg} / \mathrm{ml}$ saponins exhibited $61.66 \pm 1.20$ and $66.67 \pm 0.67 \%$ mortality against $R$. dominica and $T$. castaneum respectively. Among other fractions, chloroform was more effective against $R$. dominica and $T$. castaneum showing

Table 4 Antibacterial activity of Isodon rugosus against various bacterial strains expressed in $\mathrm{mm}$ as ZOI

\begin{tabular}{lllllllll}
\hline Samples & $P . m$ & S. $a$ & E. $c$ & B. $c$ & S. $t$ & K. $p$ & P. $a$ & E.f \\
\hline Ir.Cr & $17.2 \pm 0.37$ & $9.1 \pm 0.34$ & $7.2 \pm 0.55$ & - & $28.2 \pm 0.40$ & $18.2 \pm 0.35$ & $9.3 \pm 0.31$ & $21.3 \pm 0.36$ \\
Ir.Hex & $07.3 \pm 0.34$ & $9.1 \pm 0.52$ & - & $7.1 \pm 0.49$ & $18.2 \pm 0.37$ & $17.2 \pm 0.37$ & $8.3 \pm 0.25$ & $23.3 \pm 0.36$ \\
Ir.Cf & $11.2 \pm 0.32$ & $19.2 \pm 0.47$ & $7.1 \pm 0.26$ & - & $6.1 \pm 0.46$ & $15.3 \pm 0.35$ & $9.2 \pm 0.31$ & $19.3 \pm 0.39$ \\
Ir.EtAc & $9.2 \pm 0.40$ & $29.3 \pm 0.28$ & $21.2 \pm 0.40$ & $17.1 \pm 0.46$ & $28.2 \pm 0.35$ & $18.2 \pm 0.40$ & $7.1 \pm 0.46$ & $8.2 \pm 0.37$ \\
Ir.Aq & $21.2 \pm 0.31$ & $9.2 \pm 0.31$ & - & $13.2 \pm 0.20$ & $9.2 \pm 0.40$ & $9.2 \pm 0.40$ & $17.2 \pm 0.37$ & - \\
$\quad$ Ir.Sp & $18.2 \pm 0.43$ & $27.2 \pm 0.23$ & $24.1 \pm 0.52$ & $26.3 \pm 0.34$ & $8.2 \pm 0.37$ & $21.3 \pm 0.39$ & $9.2 \pm 0.40$ & $19.3 \pm 0.38$ \\
Ir.Flv & $33.1 \pm 0.49$ & $16.2 \pm 0.54$ & $12.2 \pm 0.54$ & $31.3 \pm 0.31$ & $16.2 \pm 0.23$ & $27.3 \pm 0.35$ & $19.2 \pm 0.38$ & $13.2 \pm 0.45$ \\
Ceft & $35.2 \pm 0.37$ & $31.1 \pm 0.34$ & $9.2 \pm 0.44$ & $29.3 \pm 0.42$ & $19.2 \pm 0.37$ & $25.4 \pm 0.40$ & $36.1 \pm 0.34$ & $21.3 \pm 0.41$ \\
\hline
\end{tabular}

Results are expressed as zone of inhibition (ZOI). Data is represented as mean \pm SEM, $(n=3)$.

Keys:

P. m Proteus mirabilis, S. a Streptococcus aureus, E. c Escherichia coli, B. c Bacillus cereus, S. $t$ Salmonella typhi, K. p Klebsiella pneumonia, P. a Pseudomonas aeruginosa E. $f$ Enterococcus faecalis, Ir.Cr Crude methanolic extract, Ir.Hex $n$-hexane fraction, Ir.Cf Chloroform fraction, Ir.EtAc Ethyl acetate fraction, Ir.Aq Aqueous fraction, Ir.Sp Saponins, Ir.FI Flavonoids, Ceft Ceftriaxone 
Table 5 Minimum inhibitory concentrations for different fractions of Isodon rugosus against the tested bacterial strains expressed as $\mu \mathrm{g} / \mathrm{ml}$

\begin{tabular}{llllllll}
\hline Samples & P. $m$ & S. $a$ & E. $c$ & B. $c$ & S. $t$ & K. $p$ & P. $a$ \\
\hline Ir.Cr & $6.66 \pm 0.83$ & $2.50 \pm 0.00$ & $8.33 \pm 0.83$ & $2.66 \pm 1.30$ & $12.50 \pm 2.88$ & $8.33 \pm 0.83$ & $4.16 \pm 1.66$ \\
Ir.Hex & $18.33 \pm 0.83$ & $16.66 \pm 0.83$ & $2.83 \pm 1.16$ & $1.33 \pm 0.60$ & $8.33 \pm 2.20$ & $10.83 \pm 2.20$ & $12.50 \pm 1.44$ \\
Ir.Cf & $2.50 \pm 0.00$ & $3.66 \pm 1.96$ & $1.00 \pm 0.00$ & $5.33 \pm 2.60$ & $2.01 \pm 0.50$ & $1.16 \pm 0.66$ & $2.50 \pm 0.00$ \\
Ir.EtAc & $7.50 \pm 1.44$ & $7.50 \pm 1.44$ & $4.16 \pm 0.83$ & $2.83 \pm 1.16$ & $3.33 \pm 0.83$ & $1.33 \pm 0.60$ & $2.83 \pm 1.16$ \\
Ir.Aq & $9.16 \pm 0.83$ & $11.66 \pm 0.83$ & $10.00 \pm 1.44$ & $10.83 \pm 2.20$ & $7.50 \pm 1.44$ & $5.00 \pm 1.44$ & $5.00 \pm 1.44$ \\
Ir.Sp & $1.00 \pm 0.00$ & $0.83 \pm 0.16$ & $5.00 \pm 1.44$ & $2.50 \pm 0.00$ & $4.50 \pm 1.89$ & $1.00 \pm 0.00$ & $3.33 \pm 0.83$ \\
Ir.Flv & $2.83 \pm 1.16$ & $1.00 \pm 0.00$ & $1.50 \pm 0.50$ & $6.66 \pm 2.20$ & $2.00 \pm 0.50$ & $2.66 \pm 1.30$ & $5.00 \pm 1.44$ \\
Ceftriaxone & $0.50 \pm 0.00$ & $0.66 \pm 0.16$ & $2.50 \pm 0.00$ & $0.83 \pm 0.16$ & $0.66 \pm 0.16$ & $0.50 \pm 0.00$ & $1.33 \pm 0.60$ \\
\hline
\end{tabular}

Data is represented as mean $\pm \mathrm{SEM},(n=3)$

Keys:

P. m Protius mirabilis, S. a Streptococcus aureus, E. c Escherichia coli, B. c Bacillus cereus, S. $t$ Salmonella typhi, K. p Klebsiella pneumonia, P. a Pseudomonas aeruginosa, E. $f$ Enterococcus faecalis, Ir.Cr Crude methanolic extract, Ir.Hex $n$-hexane fraction, Ir.Cf Chloroform fraction, Ir.EtAc Ethyl acetate fraction, Ir.Aq Aqueous fraction, Ir.Sp Saponins, Ir.FI Flavonoids

Table 6 Anthelmintic activity of aerial part of Isodon rugosus against Pheretima posthuma and Ascaridia galli

\begin{tabular}{|c|c|c|c|c|c|}
\hline \multirow[t]{2}{*}{ Samples } & \multirow{2}{*}{$\begin{array}{l}\text { Concentration } \\
(\mathrm{mg} / \mathrm{ml})\end{array}$} & \multicolumn{2}{|l|}{ Pheretima posthuma } & \multicolumn{2}{|l|}{ Ascaridia galli } \\
\hline & & $\begin{array}{l}\text { Paralysis time in Minutes } \\
\text { (mean } \pm \text { SD) }\end{array}$ & $\begin{array}{l}\text { Death time in Minutes } \\
\text { (mean } \pm \text { SD) }\end{array}$ & $\begin{array}{l}\text { Paralysis time in Minutes } \\
\text { (mean } \pm \mathrm{SD})\end{array}$ & $\begin{array}{l}\text { Death time in Minutes } \\
\text { (mean } \pm \text { SD) }\end{array}$ \\
\hline \multirow[t]{3}{*}{ Ir.Cr } & 10 & $24.33 \pm 1.15^{* * *}$ & $67.00 \pm 2.00^{* * *}$ & $20.25 \pm 0.57^{* * *}$ & $69.39 \pm 0.60^{* * *}$ \\
\hline & 20 & $18.67 \pm 1.53^{* *}$ & $60.00 \pm 2.00^{* * *}$ & $17.01 \pm 0.46^{* * *}$ & $61.18 \pm 0.67^{* * *}$ \\
\hline & 40 & $11.33 \pm 1.56^{\mathrm{ns}}$ & $40.67 \pm 1.53^{* * *}$ & $13.48 \pm 0.52^{* * *}$ & $53.19 \pm 0.36^{* * *}$ \\
\hline \multirow[t]{3}{*}{ Ir.Hex } & 10 & $23.33 \pm 2.08^{* * *}$ & $67.33 \pm 2.08^{* * *}$ & $28.89 \pm 0.52^{* * *}$ & $87.34 \pm 0.78^{* * *}$ \\
\hline & 20 & $17.00 \pm 1.00^{*}$ & $62.33 \pm 1.53^{* * *}$ & $17.32 \pm 0.96^{* * *}$ & $71.36 \pm 0.56^{* * *}$ \\
\hline & 40 & $11.67 \pm 1.53^{\mathrm{ns}}$ & $49.00 \pm 1.00^{* * *}$ & $3.43 \pm 0.67^{* *}$ & $56.63 \pm 0.38^{* * *}$ \\
\hline \multirow[t]{3}{*}{ Ir.Cf } & 10 & $14.00 \pm 1.00^{\mathrm{ns}}$ & $50.00 \pm 1.00^{\mathrm{ns}}$ & $14.53 \pm 0.67^{\mathrm{ns}}$ & $53.01 \pm 0.44^{* * *}$ \\
\hline & 20 & $10.00 \pm 2.00^{\mathrm{ns}}$ & $37.67 \pm 1.53^{\mathrm{ns}}$ & $11.95 \pm 0.34^{\mathrm{ns}}$ & $41.77 \pm 0.40^{\mathrm{ns}}$ \\
\hline & 40 & $7.33 \pm 1.53^{\mathrm{ns}}$ & $30.67 \pm 2.52^{\mathrm{ns}}$ & $9.85 \pm 0.50^{\mathrm{ns}}$ & $34.39 \pm 0.55^{\mathrm{ns}}$ \\
\hline \multirow[t]{3}{*}{ Ir.EtAc } & 10 & $18.00 \pm 2.00^{\mathrm{ns}}$ & $52.00 \pm 2.00^{\mathrm{ns}}$ & $18.13 \pm 0.49^{* * *}$ & $58.37 \pm 1.16^{* * *}$ \\
\hline & 20 & $13.00 \pm 2.00^{\mathrm{ns}}$ & $45.00 \pm 2.00^{*}$ & $13.63 \pm 0.40^{* *}$ & $49.31 \pm 0.82^{* * *}$ \\
\hline & 40 & $10.00 \pm 2.00^{\mathrm{ns}}$ & $38.67 \pm 1.53^{* *}$ & $10.29 \pm 0.56^{*}$ & $42.25 \pm 0.89^{* * *}$ \\
\hline \multirow[t]{3}{*}{ Ir.Aq } & 10 & $21.00 \pm 2.00^{* *}$ & $61.00 \pm 2.00^{* * *}$ & $19.66 \pm 0.88_{* * *}$ & $68.54 \pm 0.81^{* * *}$ \\
\hline & 20 & $19.00 \pm 2.00^{* *}$ & $56.00 \pm 2.00^{* * *}$ & $15.4 \pm 0.61^{* * *}$ & $57.15 \pm 0.85^{* * *}$ \\
\hline & 40 & $15.00 \pm 2.00^{* *}$ & $47.67 \pm 1.53^{* * *}$ & $13.40 \pm 0.69^{* * *}$ & $52.85 \pm 0.50^{* * *}$ \\
\hline \multirow[t]{3}{*}{ Ir.Sp } & 10 & $13.33 \pm 1.53^{\mathrm{ns}}$ & $44.00 \pm 2.00^{\mathrm{ns}}$ & $8.40 \pm 0.9^{* * *}$ & $43.00 \pm 1.00^{* *}$ \\
\hline & 20 & $9.00 \pm 2.00^{\mathrm{ns}}$ & $33.67 \pm 3.05^{\mathrm{ns}}$ & $8.33 \pm 0.58^{\mathrm{ns}}$ & $32.79 \pm 0.54^{* * *}$ \\
\hline & 40 & $5.67 \pm 1.53^{\text {ns }}$ & $27.67 \pm 1.53^{\mathrm{ns}}$ & $4.33 \pm 0.58^{\mathrm{ns}}$ & $29.22 \pm 0.61^{* *}$ \\
\hline \multirow[t]{3}{*}{ Albendazole } & 10 & $12.33 \pm 2.08$ & $48.67 \pm 1.53$ & $13.10 \pm 1.85$ & $47.40 \pm 1.50$ \\
\hline & 20 & $10.33 \pm 2.57$ & $37.33 \pm 1.53$ & $9.80 \pm 1.60$ & $40.20 \pm 2.25$ \\
\hline & 40 & $7.00 \pm 2.00$ & $28.67 \pm 1.53$ & $7.10 \pm 1.01$ & $33.60 \pm 1.76$ \\
\hline Negative control & -—— & -—- & -—— & -—- & -——— \\
\hline
\end{tabular}

Values significantly different $\left({ }^{*}: P<0.05,{ }^{* *} P<0.01\right.$ and $\left.{ }^{* * *} P<0.001\right)$ as compared to positive control drug. ns: Non significantly different in comparion to control group

Keys:

Ir.Cr Crude methanolic extract, Ir.Hex $n$-hexane fraction, Ir.Cf Chloroform fraction, Ir.EtAc Ethyl acetate fraction, Ir.Aq Aqueous fraction, Ir.Sp Saponins. 


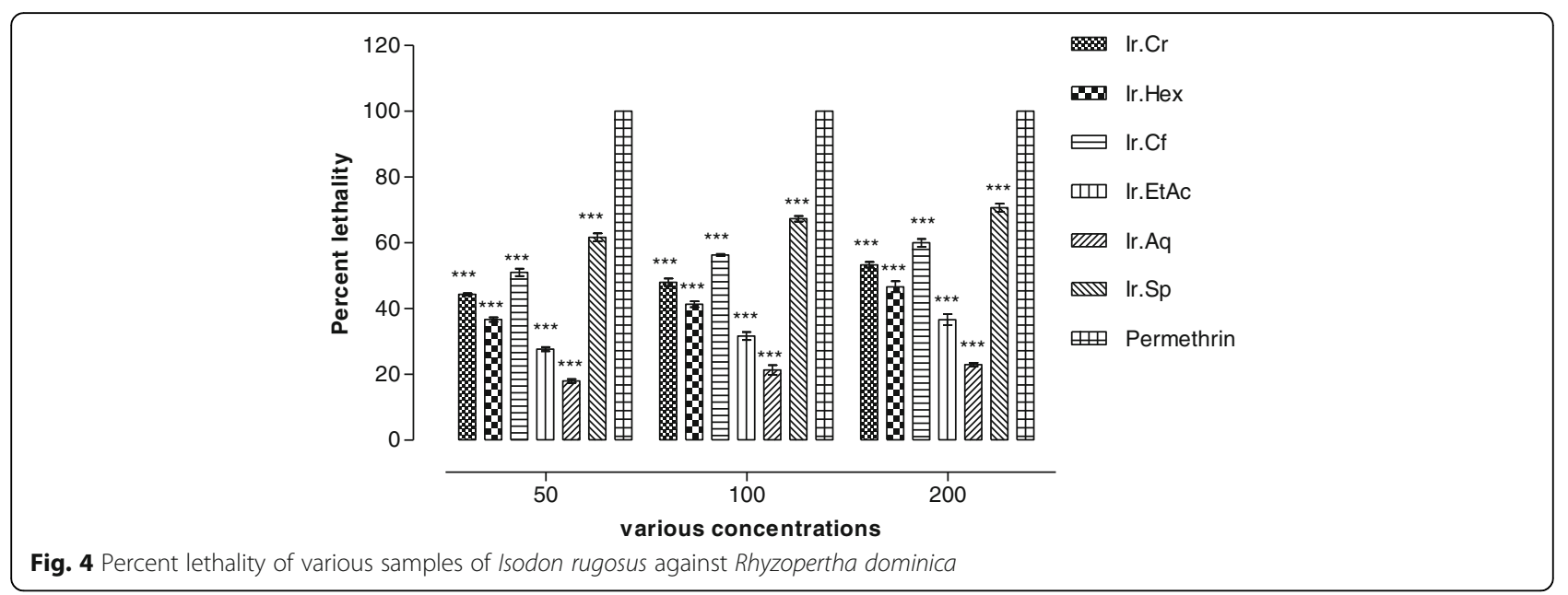

$60.00 \pm 1.15$ and $70.33 \pm 0.88 \%$ mortality against $R$. dominica and T. castaneum respectively at concentration of $200 \mathrm{mg} / \mathrm{ml}$, while showed $51.00 \pm 1.15$ and $59.00 \pm 0.57 \%$ mortality against $R$. dominica and $T$. castaneum respectively at a concentration of $50 \mathrm{mg} / \mathrm{ml}$. The methanolic extract and $n$-hexane fraction also showed moderate insecticidal effects against both the insects as shown in Figs. 4 and 5.

\section{Anti-termite activity}

The anti-termite activity of various samples of I. rugosus showed prominent lethality against termites. The highest activity was attributed to saponins, killing almost all the termites on the first day as shown in Table 7. The second highest activity was shown by ethyl acetate fraction which demonstrated $93.00 \pm 0.57 \%$ lethality on the first day and $100 \%$ lethality on the second day. Other fractions including chloroform, $n$-hexane and aqueous fractions showed moderate activity causing $77.32 \pm 1.32$,
$50.33 \pm 0.88$ and $48.33 \pm 0.88 \%$ lethality respectively on the first day. On the third day almost all the insects were killed by all the plant's samples.

\section{Anti-Pharaoh (ants) activity}

The determination of anti-Pharaoh ants potentials of $I$. rugosus reveal that among all the plant's samples, saponins showed $100 \%$ activity against Pharaoh at all the tested concentrations except at $0.5 \mathrm{mg} / \mathrm{ml}$ which was $96.33 \pm 0.88 \%$. The second highest activity can be attributed to the ethyl acetate fractions of I. rugosus which displayed $72.00 \pm 1.15,77.67 \pm 0.67,80.33 \pm 0.33$, $86.33 \pm 0.88,90.67 \pm 0.67$ and $100.0 \pm 0.57 \%$ lethality at concentrations of $0.5,1,2,4,6$ and $8 \mathrm{mg} / \mathrm{ml}$ respectively. The $\mathrm{LD}_{50}$ shown by saponins, ethyl acetate and chloroform fractions were smaller than $0.1 \mathrm{mg} / \mathrm{ml}$, whereas $\mathrm{LD}_{50}$ for methanolic extract, $n$-hexane and aqueous fractions were $0.85,1.13$ and $3.37 \mathrm{mg} / \mathrm{ml}$ respectively as shown in Table 8.

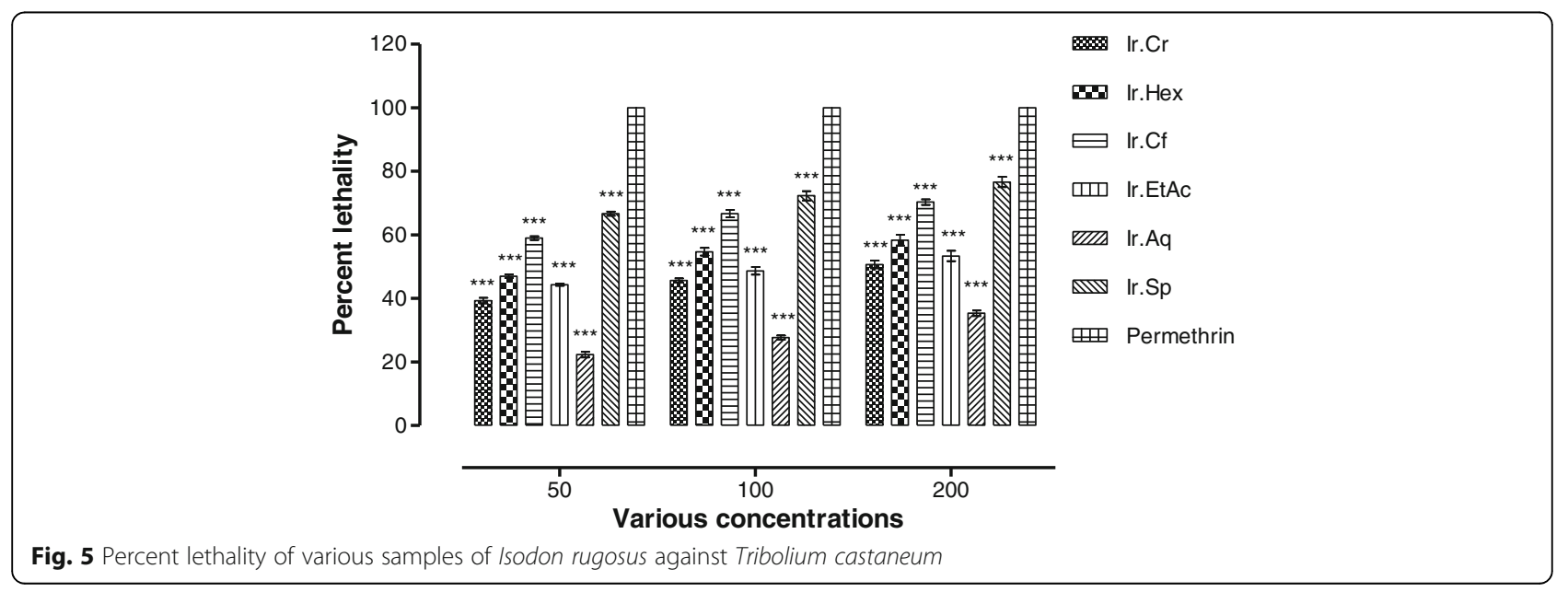


Table 7 Anti-termite effect of various samples of Isodon rugosus

\begin{tabular}{|c|c|c|c|}
\hline Samples & $\begin{array}{l}\text { Number of Termites } \\
\text { treated }\end{array}$ & Days & $\begin{array}{l}\text { Percent lethality } \\
\text { (mean } \pm \text { SEM) }\end{array}$ \\
\hline \multirow[t]{3}{*}{ Ir.Cr } & 25 & 1 & $45.00 \pm 1.15^{* * *}$ \\
\hline & & 2 & $77.32 \pm 1.32^{* * *}$ \\
\hline & & 3 & $100.0 \pm 0.00^{\mathrm{ns}}$ \\
\hline \multirow[t]{3}{*}{ Ir.Hex } & 25 & 1 & $50.33 \pm 0.88^{* * *}$ \\
\hline & & 2 & $69.32 \pm 1.32^{* * *}$ \\
\hline & & 3 & $100.0 \pm 0.00^{\mathrm{ns}}$ \\
\hline \multirow[t]{3}{*}{ Ir.Cf } & 25 & 1 & $77.32 \pm 1.32^{* * *}$ \\
\hline & & 2 & $96.67 \pm 1.20^{\mathrm{ns}}$ \\
\hline & & 3 & $100.0 \pm 0.00^{\mathrm{ns}}$ \\
\hline \multirow[t]{3}{*}{ Ir.EtAc } & 25 & 1 & $93.00 \pm 0.57^{\mathrm{ns}}$ \\
\hline & & 2 & $100.0 \pm 0.00^{\mathrm{ns}}$ \\
\hline & & 3 & $100.0 \pm 0.00^{\mathrm{ns}}$ \\
\hline \multirow[t]{3}{*}{ Ir.Aq } & 25 & 1 & $48.33 \pm 0.88^{* * *}$ \\
\hline & & 2 & $74.00 \pm 0.57^{* * *}$ \\
\hline & & 3 & $100.0 \pm 0.00^{\mathrm{ns}}$ \\
\hline \multirow[t]{3}{*}{ Ir.Sp } & 25 & 1 & $100.0 \pm 0.00^{\mathrm{ns}}$ \\
\hline & & 2 & $100.0 \pm 0.00^{\mathrm{ns}}$ \\
\hline & & 3 & $100.0 \pm 0.00^{\mathrm{ns}}$ \\
\hline Permethrin & 25 & 123 & \\
\hline
\end{tabular}

$100.0 \pm 0.00100 .0 \pm$

$0.00100 .0 \pm 0.00 \mathrm{Data}$ is represented as mean $\pm \mathrm{SEM} ;(n=3)$. Values significantly different

$(* * * P<0.001)$ as compared to the control drug

Keys:

Ir.Cr Crude methanolic extract, Ir.Hex $n$-hexane fraction, Ir.Cf Chloroform fraction, Ir.EtAc Ethyl acetate fraction, Ir.Aq Aqueous fraction, Ir.Sp Saponins

\section{Discussion}

The origin and nature of drug used against specific diseases make a sound difference in the therapy and prognosis. The efficacy and safety of synthetic and natural drugs have been investigated and compared by multiple reporters [39, 40]. Similarly, the use of drugs derived from natural sources have been found comparatively safe and have been preferred against synthetic drugs [41]. Several groups of natural compounds have been reported to possess variety of potentials, for examples, flavonoids have been shown to possess antimicrobial activity that is also obvious in our current study [42]. Similarly, parasitic worms causing infections of human beings and animals are well-known to have negative health consequences and a significant reduction in body ability to resist other diseases. To find compounds with anthelmintic activity, a variety of substances have been investigated using different species of worms like earthworms, ascaris, heterakis and nippostrongylus [42, 43]. Among all these species, earthworms have been used generally for the preliminary evaluation of anthelmintic compounds in-vitro due to physiological similarity with intestinal worms, their reaction to anthelmintics and are easily accessible [44]. It has been established that all those anthelmintics which are toxic to earthworms are regarded as anthelmintic agents. To minimize losses caused by helminths infections, commercial anthelminthics have been used for decades. However, the threats of anthelminthic resistance, poor availability, risk of residue and high cost especially to low income people in developing countries have led to the need of other alternative control methods [45]. Screening and proper evaluation of the claimed medicinal plants could offer the possible alternatives that may both be sustainable and environmentally acceptable instead of those having toxic effect [46].

Results of the current study reveal that saponins were most effective against $P$. posthuma exhibiting an average death time of $27.67 \pm 1.53$ min which was comparable with the standard drug albendazole with average death time of $28.67 \pm 1.53$ at the same concentration $(40 \mathrm{mg} /$ $\mathrm{ml})$. Furthermore, crude saponins were most effective against Ascaridia galli with average death time of $29.22 \pm 0.61 \mathrm{~min}$ at $40 \mathrm{mg} / \mathrm{ml}$. The average death time for standard drug albendazole was $33.6 \pm 1.76$ at the same concentration. Researchers have proven that saponins possess excellent anthelmintic potential which has also been depicted in our investigations [36].

In the current study, we observed that saponins were also active against insects in a similar way reported earlier [47]. Moreover, the saponins have also been reported to possess anthelmintic, antitussive, anticancer, fungicidal and antiviral properties [48-51]. Actually the saponins help the plants to protect against pests and parasites [49, 52-55]. Saponins may cause inhibition of food uptake in the insects' gut and interrupt in their digestion which lead to stop their growth [47]. They are considered as first line choice for the proper eradication of insects due to their protease inhibitory properties and interaction with cholesterol by disturbing the synthesis of moulting hormones [56]. The saponins isolated from various plants have been reported to possess toxicity profile and have been demonstrated with prominent haemolytic potential. The haemolytic potential and toxicity profile of the saponins make it inevitable that the saponins of each and every plant should be subjected for the evaluation of safety profile in regards to the human body.

The GC-MS analysis showed 57 compounds in the ethyl acetate fraction of I. rugosus. The bioactive compounds identified were palmitic acid, hinokiol, $\alpha$-amyrin, phytol, ethyl linolate, cyclohexanone, hinokione, methyl palmitate, ethyl palmitate and stigma sterol acetate. The literature survey of the bioactive compounds reveals the importance of $I$. rugosus regarding various biological activities. The compounds identified in this plant have been reported previously with significant biological activities. Cyclohexanone possess strong antibacterial 
Table 8 Anti-Pharaoh ant effect of various samples of Isodon rugosus

\begin{tabular}{|c|c|c|c|c|c|}
\hline Samples & Dose $(\mathrm{mg} / \mathrm{ml})$ & Total treated & No. repeated & Mortality(\%) mean \pm SEM & $\mathrm{LD}_{50}(\mathrm{mg} / \mathrm{ml})$ \\
\hline \multirow[t]{6}{*}{ Ir.Cr } & 0.5 & 20 & \multirow[t]{6}{*}{3} & $41.33 \pm 0.88^{* * *}$ & \multirow[t]{6}{*}{0.85} \\
\hline & 1 & 20 & & $52.00 \pm 0.57^{* * *}$ & \\
\hline & 2 & 20 & & $57.67 \pm 0.67^{* * *}$ & \\
\hline & 4 & 20 & & $58.00 \pm 0.57^{* * *}$ & \\
\hline & 6 & 20 & & $70.00 \pm 0.00^{* * *}$ & \\
\hline & 8 & 20 & & $81.33 \pm 0.88^{* * *}$ & \\
\hline \multirow[t]{6}{*}{ Ir.Hex } & 0.5 & 20 & \multirow[t]{6}{*}{3} & $39.67 \pm 1.20^{* * *}$ & \multirow[t]{6}{*}{1.13} \\
\hline & 1 & 20 & & $49.00 \pm 1.15^{* * *}$ & \\
\hline & 2 & 20 & & $53.00 \pm 0.57^{* * *}$ & \\
\hline & 4 & 20 & & $56.67 \pm 0.67^{* * *}$ & \\
\hline & 6 & 20 & & $58.00 \pm 0.57^{* * *}$ & \\
\hline & 8 & 20 & & $80.67 \pm 1.20^{* * *}$ & \\
\hline \multirow[t]{6}{*}{ Ir.Cf } & 0.5 & 20 & \multirow[t]{6}{*}{3} & $67.33 \pm 1.45^{* * *}$ & \multirow[t]{6}{*}{$<0.1$} \\
\hline & 1 & 20 & & $68.67 \pm 0.67^{* * *}$ & \\
\hline & 2 & 20 & & $73.33 \pm 0.88^{* * *}$ & \\
\hline & 4 & 20 & & $76.00 \pm 1.15^{* * *}$ & \\
\hline & 6 & 20 & & $85.00 \pm 0.57^{* *}$ & \\
\hline & 8 & 20 & & $95.33 \pm 0.88^{\text {ns }}$ & \\
\hline \multirow[t]{6}{*}{ Ir.EtAc } & 0.5 & 20 & \multirow[t]{6}{*}{3} & $72.00 \pm 1.15^{* * *}$ & \multirow[t]{6}{*}{$<0.1$} \\
\hline & 1 & 20 & & $77.67 \pm 0.67^{* * *}$ & \\
\hline & 2 & 20 & & $80.33 \pm 0.33^{* *}$ & \\
\hline & 4 & 20 & & $86.33 \pm 0.88^{*}$ & \\
\hline & 6 & 20 & & $90.67 \pm 0.67^{\mathrm{ns}}$ & \\
\hline & 8 & 20 & & $100.0 \pm 0.57^{\mathrm{ns}}$ & \\
\hline \multirow[t]{6}{*}{ Ir.Aq } & 0.5 & 20 & \multirow[t]{6}{*}{3} & $29.00 \pm 1.15^{* * *}$ & \multirow[t]{6}{*}{3.37} \\
\hline & 1 & 20 & & $41.33 \pm 0.88^{* * *}$ & \\
\hline & 2 & 20 & & $44.67 \pm 1.20^{* * *}$ & \\
\hline & 4 & 20 & & $53.33 \pm 0.33^{* * *}$ & \\
\hline & 6 & 20 & & $66.00 \pm 0.57^{* * *}$ & \\
\hline & 8 & 20 & & $80.67 \pm 1.76^{* * *}$ & \\
\hline \multirow[t]{6}{*}{ Ir.Sp } & 0.5 & 20 & \multirow[t]{6}{*}{3} & $96.33 \pm 0.88^{\text {ns }}$ & \multirow[t]{6}{*}{$<0.1$} \\
\hline & 1 & 20 & & $100.0 \pm 0.00^{\mathrm{ns}}$ & \\
\hline & 2 & 20 & & $100.0 \pm 0.00^{\mathrm{ns}}$ & \\
\hline & 4 & 20 & & $100.0 \pm 0.00^{\mathrm{ns}}$ & \\
\hline & 6 & 20 & & $100.0 \pm 0.00^{\mathrm{ns}}$ & \\
\hline & 8 & 20 & & $100.0 \pm 0.00^{\mathrm{ns}}$ & \\
\hline \multirow[t]{6}{*}{ Permithrin } & 0.5 & 20 & \multirow[t]{6}{*}{3} & $93.33 \pm 4.40$ & \multirow[t]{6}{*}{$<0.1$} \\
\hline & 1 & 20 & & $98.33 \pm 1.66$ & \\
\hline & 2 & 20 & & $100.0 \pm 0.00$ & \\
\hline & 4 & 20 & & $100.0 \pm 0.00$ & \\
\hline & 6 & 20 & & $100.0 \pm 0.00$ & \\
\hline & 8 & 20 & & $100.0 \pm 0.00$ & \\
\hline Distilled Water & Negative control & 20 & 3 & 0.00 & 0.00 \\
\hline
\end{tabular}

Data is represented as mean $\pm \mathrm{SEM} ;(n=3)$. Values significantly different $\left(^{*}: P<0.05,{ }^{*} P<0.01\right.$ and $\left.{ }^{* * *} P<0.001\right)$ as compared to the control drug Keys:

Ir.Cr Crude methanolic extract, Ir.Hex $n$-hexane fraction, Ir.Cf Chloroform fraction, Ir.EtAc Ethyl acetate fraction, Ir.Aq Aqueous fraction, Ir.Sp Saponins. 
activity [57]. Red and white wine containing succinic acid have been reported with strong antibacterial activity [58]. The succinic acid derivatives have been reported to treat the infants urinary tract infection [59]. Similarly, the succinic acid have also been reported for antibacterial potential produced by yeast during fermentation [60]. Palmitic acid have been reported to possess antimicrobial potential $[61,62]$. Phytol have been reported for its antibacterial [63], antimicrobial [64] and insecticidal potentials [62]. Hinokiol isolated from Magnolia officinalis have been used for antibacterial activity [65]. Ethyl linolate have been used for the treatment of acne vulgaris [66] and topically as antibacterial agent [67]. In the same way, stigmasterol acetate has also been used as antibacterial agent [68]. Likewise, alpha-amyrin possess strong antibacterial activity [69]. Cyclohexanone have been reported to used as a solvent and as a building block in the production of various organic compounds such as insecticidal [70]. Methyl palmitate have been reported to possess insecticidal activity [71]. Palmitic acid have been reported to possess strong anti mosquitoes activities isolated from Acanthus montanus [72]. Ethyl palmitate is larvicidal and insecticidal agent and has been used in insecticidal sprays [73]. Similarly, hinokione isolated from Sabina vulgaris have been reported to possess insecticidal potential [74]. Stigmasterol acetate has mosquito repellent property [75]. Alpha-Amyrin have been reported for insecticidal activity [69].

\section{Conclusions}

It can be concluded that Isodon rugosus possess strong antibacterial, insecticidal and anthelmintic potentials. The gas chromatography-mass spectroscopy analysis also elucidated a collection of biologically important compounds putatively known for their antibacterial, insecticidal and anthelmintic potentials. Based on the experimental analysis, it may also be deduced that Isodon rugosus is a good source of antibacterial, insecticidal and anthelmintic compounds. The overwhelming role of ethyl acetate fraction in various biological assays and the GC-MS analysis confirm that this fraction might be an appropriate target for the isolation of bioactive compounds.

\footnotetext{
Abbreviations

B. c: Bacillus cereus; E. c: Escherichia coli; E. f: Enterococcus faecalis; GC-MS: gas chromatography-mass spectrometry; Ir.Aq: aqueous fraction; Ir.Cf: chloroform fraction; Ir.Cr: Crude methanolic extract; Ir.EtAc: ethyl acetate fraction; Ir.Fl: flavonoids; Ir.Hex: $n$-hexane fraction; Ir.Sp: saponins; K. p: Klebsiella pneumonia; LD $_{50}$ : median lethal dose; MDR: multi drug resistant; MIC: minimum inhibitory concentration; NCCLS: National Committee for Clinical Laboratory Standards; P. a: Pseudomonas aeruginosa.; P. m: Protius mirabilis; S. a: Streptococcus aureus; S. t: Salmonella typhi; SEM: standard error mean; ZOI: zone of inhibition
}

\section{Acknowledgements}

The authors are grateful to the plant taxonomist Ali Hazrat at Shaheed Benazir Bhuto University Dir (KPK), Pakistan for the identification of plant sample. All the authors are also thankful to the HEJ, University of Karachi, Pakistan for the GC-MS analysis.

\section{Funding}

This research received no specific grant from any funding agency in the public, commercial, or not-for-profit sectors.

\section{Availability of data and materials}

The data supporting our research results is present within the manuscript.

\section{Authors' contributions}

AZ and SA carried out experimental work, data collection and evaluation, literature search and manuscript preparation under the supervision of AS. MA, AS and FU refined the manuscript for publication. All authors read and approved the final manuscript for publication.

\section{Competing interests}

The authors declare that they have no competing interest.

\section{Consent for publication}

Not application for this submission.

Ethics approval and consent to participate

Not application for this submission.

\section{Publisher's Note}

Springer Nature remains neutral with regard to jurisdictional claims in published maps and institutional affiliations.

Received: 15 July 2016 Accepted: 17 May 2017

Published online: 30 May 2017

\section{References}

1. Noumedem JAK, Mihasan M, Lacmata ST. Antibacterial activities of the methanol extracts of ten Cameroonian vegetables against gram-negative multidrug-resistant bacteria. BMC Complement Altern Med. 2013;13:26.

2. Okeke IN, Laxminarayan R, Bhutta ZA, Duse AG, Jenkins P, O'Brien TF, et al Antimicrobial resistance in developing countries. Part I: recent trends and current status. Lancet Infect Dis. 2005;5(8):481-93.

3. Ayaz M, Subhan F, Sadiq A, Ullah F, Ahmed J, Sewell R. Cellular efflux transporters and the potential role of natural products in combating efflux mediated drug resistance. Front Biosci. 2017;22:732.

4. Ayaz M, Subhan F, Ahmed J, Khan A-U, Ullah F, Sadiq A, et al. Citalopram and Venlafaxine differentially augments antimicrobial properties of antibiotics. Acta Poloniae Pharmaceutica ñ Drug Research. 2015:72(6):1269-78.

5. Bandow JE, Brötz H, Leichert LIO, Labischinski H, Hecker M. Proteomic approach to understanding antibiotic action. Antimicrob Agents Chemother. 2003;47(3):948-55.

6. Ullah F, Malik SA, Ahmed J, Ullah F, Shah SM, Ayaz M, et al. Investigation of the genetic basis of tetracycline resistance in Staphylococcus aureus from Pakistan. Trop J Pharm Res. 2012;11(6):925-31.

7. Khalafi-Nezhad A, Rad M, Mohabatkar H, Asrari Z, Hemmateenejad B. Design, synthesis, antibacterial and QSAR studies of benzimidazole and imidazole chloroaryloxyalkyl derivatives. Bioorg Med Chem. 2005;13:1931-8.

8. Clardy J, Walsh C. Lessons from natural molecules. Nature. 2004;432:829-37.

9. Ullah F, Ayaz M, Sadiq A, Hussain A, Ahmad S, Imran M, et al. Phenolic, flavonoid contents, anticholinesterase and antioxidant evaluation of Iris germanica var; florentina. Nat Prod Res. 2016;30(12):1440-4.

10. Dhar D, Sharma R, Bansal G. Gastro-intestinal nematodes in sheep in Kashmir. Vet Parasitol. 1982:11(2):271-7.

11. Blumenthal DS, Schultz MG. Incidence of intestinal obstruction in children infected with Ascaris Lumbricoides. AmJTrop Med Hyg. 1975;24(5):801-5.

12. Tagboto S, Townson S. Antiparasitic properties of medicinal and other naturally occurring products. Adv Parasitol. 2001;50:199-295.

13. Chiejina S. The epidemiology of helminth infections of domesticated animals in the tropics with emphasis on fascioliasis and parasitic gastroenteritis. Perspect Helminthol. 2001:41-87. 
14. Liu LX, Weller PF. Antiparasitic drugs. N Engl J Med. 1996;334(18):1178.

15. Calabrese EJ, Baldwin LA. Toxicology rethinks its central belief. Nature. 2003:421 (6924):691-2.

16. Duke SO, Baerson SR, Dayan FE, Rimando AM, Scheffler BE, Tellez MR, et al. United States Department of agriculture-agricultural research service research on natural products for pest management. Pest Manag Sci. 2003;59(6-7):708-17.

17. Ayaz M, Junaid M, Ullah F, Sadiq A, Ovais M, Ahmad W, Ahmad S, Zeb A: Chemical profiling, antimicrobial and isecticidal evaluations of Polygonum hydropiper L. BMC Complement Altern Med. 2016;16:502.

18. Harris ES. Not-so-traditional Chinese medicine: the example of Donglingcao (Isodon rubescens). Arnoldia. 2011;68(4):23-30.

19. Janbaz KH, Arif J, Saqib F, Imran I, Ashraf M, Zia-UI-Haq M, et al. In-vitro and in-vivo validation of ethnopharmacological uses of methanol extract of Isodon rugosus Wall. Ex Benth.(Lamiaceae). BMC Complement Altern Med. 2014;14(1):71

20. Haq F, Ahmad H, Ullah R, labal Z. Species diversity and ethno botanical classes of the Flora of Allai Valley district Battagram Pakistan. Int J Plant Res. 2012;2(4):111-23.

21. Ahmad M, Sultana S, Fazl-i-Hadi S, Ben Hadda T, Rashid S, Zafar M, et al. An Ethnobotanical study of medicinal plants in high mountainous region of Chail valley (district swat-Pakistan). J Ethnobiol Ethnomed. 2014;10(1):1.

22. Sabeen M, Ahmad SS. Exploring the folk medicinal flora of Abbotabad city Pakistan. Ethnobotanical Leaflets. 2009;2009(7):1.

23. Zeb A, Ahmad S, Ullah F, Ayaz M, Sadia A: Anti-nociceptive activity of ethnomedicinally important analgesic plant Isodon rugosus Wall. ex Benth: Mechanistic study and identifications of bioactive compounds. Front Pharmacol. 2016;7:200.

24. Ayaz M, Junaid M, Ahmed J, Ullah F, Sadiq A, Ahmad S, et al. Phenolic contents, antioxidant and anticholinesterase potentials of crude extract, subsequent fractions and crude saponins from Polygonum hydropiper $\mathrm{L}$. BMC Complement Altern Med. 2014;14(1):145.

25. Ahmad S, Ullah F, Ayaz M, Zeb A, Ullah F, Sadiq A. Antitumor and antiangiogenic potentials of isolated crude saponins and various fractions of Rumex hastatus D. Don. Biol Res. 2016;49(1):1.

26. Zeb A, Sadiq A, Ullah F, Ahmad S, Ayaz M. Phytochemical and toxicological investigations of crude methanolic extracts, subsequent fractions and crude saponins of Isodon rugosus. Biol Res. 2014;47(1):57.

27. Ayaz M, Junaid M, Ullah F, Sadiq A, Subhan F, Khan MA, et al. Molecularly characterized solvent extracts and saponins from Polygonum hydropiper $\mathrm{L}$ show high anti-angiogenic, anti-tumor, brine shrimp and fibroblast NIH/3T3 cell line cytotoxicity. Front Pharmacol. 2016;7:74.

28. Zeb A, Sadiq A, Ullah F, Ahmad S, Ayaz M. Investigations of anticholinestrase and antioxidant potentials of methanolic extract, subsequent fractions, crude saponins and flavonoids isolated from Isodon rugosus. Biol Res. 2014;47(1):1-10.

29. Ayaz M, Junaid M, Ullah F, Sadiq A, Khan MA, Ahmad W, et al. Comparative chemical profiling, cholinesterase inhibitions and anti-radicals properties of essential oils from Polygonum hydropiper L: a preliminary anti-Alzheimer's study. Lipids Health Dis. 2015;14(1):141.

30. Adams R. Identification of essential oil components by gas chromatography/ mass spectrometry. Carol Stream: Allured Publishing; 2007. p. 804.

31. Ayaz M, Subhan F, Ahmed J, Khan A-U, Ullah F, Ullah I, et al. Sertraline enhances the activity of antimicrobial agents against pathogens of clinical relevance. J Biol Res-Thessaloniki. 2015;22(1):4.

32. Sadiq A, Ahmad S, Ali R, Ahmad F, Ahmad S, Zeb A, et al. Antibacterial and antifungal potentials of the solvents extracts from Eryngium caeruleum, Notholirion thomsonianum and Allium consanguineum. BMC Complement Altern Med. 2016:16:478.

33. Shah SM, Ayaz M, Khan A-U, Ullah F, Farhan, Shah A-U-HA, labal H, Hussain S: 1,1-Diphenyl,2-picrylhydrazyl free radical scavenging, bactericidal, fungicidal and leishmanicidal properties of Teucrium stocksianum. Toxicology and Industrial Health 2015, 31(11):1037-1043.

34. National Committee for Clinical Laboratory Standards: 1993 Mfdastfbtga, 3rd ed., Approved standard M7-A3. NCCLS, Villanova, PA.

35. Vigar Z. Atlas of medical parasitology, vol. 2. Singapore: PG Publishing House; 1984. p. 216-7.

36. Ayaz M, Junaid M, Subhan F, Ullah F, Sadiq A, Ahmad S, et al. Heavy metals analysis, phytochemical, phytotoxic and anthelmintic investigations of crude methanolic extract, subsequent fractions and crude saponins from Polygonum hydropiper L. BMC Complement Altern Med. 2014;14(1):465.
37. Ahn Y, Kim G, Cho K: Bioassay system for insecticidal compounds. In: Proceedings of the third symposium on the biochemical methodology for the research and development of the bioactive substances, held at Seoul, Republic of Korea: 1995; 1995: 495-506.

38. Salihah Z, Khatoon R, Khan A, Alamzeb SA. A termite trap, NIFATERMAP, for capturing large number of field population of Heterotermes Indicola. Proc Pakistan Cong Zool. 1993;1993:395-400

39. Ullah I, Subhan F, Ayaz M, Shah R, Ali G, Haq IU, et al. Anti-emetic mechanisms of Zingiber officinale against cisplatin induced emesis in the pigeon; behavioral and neurochemical correlates. BMC Complement Altern Med. 2015;15(1):34.

40. Sadiq A, Mahmood F, Ullah F, Ayaz M, Ahmad S, Haq FU, et al. Synthesis, anticholinesterase and antioxidant potentials of ketoesters derivatives of succinimides: a possible role in the management of Alzheimer's. Chem Central J. 2015;9(1):31.

41. Kahl R, Kappus H. Toxicology of the synthetic antioxidants BHA and BHT in comparison with the natural antioxidant vitamin E. Zeitschrift für Le0bensmittel-Untersuchung und-Forschung. 1993;196:329-38.

42. Cushnie T, Lamb AJ. Antimicrobial activity of flavonoids. Int J Antimicrob Agents. 2005;26(5):343-56.

43. Theodorides V, Gyurik R, Kingsbury W, Parish R. Anthelmintic activity of albendazole against liver flukes, tapeworms, lung and gastrointestinal roundworms. Cell Mol Life Sci. 1976;32(6):702-3.

44. Viigar Z. Atlas of medical Parasitology. Singapore: Singapore Publishing House; 1984.

45. Waller PJ. Sustainable helminth control of ruminants in developing countries. Vet Parasitol. 1997;71(2):195-207.

46. Shah S, Shah SMM, Ahmad Z, Yaseen M, Shah R, Sadiq A, Khan S, Khan B. Phytochemicals, in vitro antioxidant, total phenolic contents and phytotoxic activity of Cornus macrophylla Wall bark collected from the north-west of Pakistan. Pak J Pharm Sci. 2015;28(1):23-8.

47. Adel MM, Sehnal F, Jurzysta M. Effects of alfalfa saponins on the moth Spodoptera Littoralis. J Chem Ecol. 2000;26(4):1065-78.

48. Wang G-X, Han J, Zhao L-W, Jiang D-X, Liu Y-T, Liu X-L. Anthelmintic activity of steroidal saponins from $<\mathrm{i}>$ Paris polyphylla</i $>$. Phytomedicine. 2010;17(14):1102-5.

49. Yan L, Zhang Y, Gao W, Man S, Wang Y. In vitro and in vivo anticancer activity of steroid saponins of Paris polyphylla var. yunnanensis. Exp Oncol. 2009;31(1):27-32.

50. Marston A, Gafner F, Dossaji S, Hostettmann K. Fungicidal and molluscicidal saponins from< i> Dolichos kilimandscharicus</i>. Phytochemistry. 1988;27(5):1325-6.

51. Amoros $M$, Fauconnier B, Girre R. In vitro antiviral activity of a saponin from $<\mathrm{i}>$ Anagallis Arvensis $</ i>$, Primulaceae, against herpes simplex virus and poliovirus. Antivir Res. 1987;8(1):13-25.

52. Milgate J, Roberts $D$. The nutritional \& biological significance of saponins. Nutr Res. 1995:15(8):1223-49.

53. Oleszek W, Hoagland R, Zablotowicz R. Ecological significance of plant saponins. Principles and Practices in Plant Ecology: Allelochemical Interactions CRC Press, New York; 1999. p. 451-65.

54. Potter DA, Kimmerer TW. Inhibition of herbivory on young holly leaves: evidence for the defensive role of saponins. Oecologia. 1989;78(3):322-9.

55. Shah SMM, Sadiq A, Shah SMH, Khan S: Extraction of saponins and toxicological profile of Teucrium stocksianum boiss extracts collected from District Swat, Pakistan. Biol Res. 2014:47(1):65.

56. Harmatha J, Dinan L. Interaction of dimeric ecdysteroids, glycosidic ecdysteroid conjugates and ecdysis-disturbing saponins with the ecdysteroid receptor assessed by means of the Drosophila melanogaster B-\| bioassay. Arthropods: Chemical, Physiological and Environmental Aspects. 2002:79-84.

57. Ovsyannikova M, Vol'eva V, Belostotskaya I, Komissarova N, Malkova A, Kurkovskaya L. Antibacterial activity of substituted 1, 3-Dioxolanes. Pharm Chem J. 2013;47(3):142-5.

58. Daglia M, Papetti A, Grisoli P, Aceti C, Dacarro C, Gazzani G. Antibacterial activity of red and white wine against oral streptococci. J Agric Food Chem. 2007:55(13):5038-42

59. Hansson S, Dhamey M, Sigström O, Sixt R, Stokland E, Wennerström M, et al. Dimercapto-succinic acid scintigraphy instead of voiding cystourethrography for infants with urinary tract infection. J Urol. 2004;172(3):1071-4.

60. Basso L, Alves D, Amorim $\mathrm{H}$. The antibacterial action of succinic acid produced by yeast during fermentation. Rev Microbiol. 1997;28:77-82. 
61. Yff BT, Lindsey KL, Taylor MB, Erasmus DG, Jäger AK. The pharmacological screening of Pentanisia prunelloides and the isolation of the antibacterial compound palmitic acid. J Ethnopharmacol. 2002;79(1):101-7.

62. Senthilkumar N, Murugesan S, Vijayalakshmi K. GC-MS-MS analysis of Trichili a connaroides (Wight \& Arn.) Bentv (Meliaceae): a tree of ethnobotanical records. Asian J Plant Sci Res. 2012;2(2):207-11.

63. Inoue Y, Hada T, Shiraishi A, Hirose K, Hamashima H, Kobayashi S. Biphasic effects of geranylgeraniol, teprenone, and phytol on the growth of Staphylococcus aureus. Antimicrob Agents Chemother. 2005;49(5):1770-4.

64. Padmini E, Valarmathi A, Rani Usha M. Comparative analysis of chemical composition and antibacterial activities of Mentha spicata and Camellia sinensis. Asian J Exp Biol Sci. 2010;1(4):772-81.

65. Ho KY, Tsai CC, Chen CP, Huang JS, Lin CC. Antimicrobial activity of honokiol and magnolol isolated from Magnolia Officinalis. Phytother Res. 2001;15(2):139-41.

66. Charakida A, Charakida M, Chu A. Double-blind, randomized, placebocontrolled study of a lotion containing triethyl citrate and ethyl linoleate in the treatment of acne vulgaris. Br J Dermatol. 2007;157(3):569-74.

67. Jelenko C, Wheeler M, Anderson A, Callaway B, McKinley J. Studies in burns: XIV, Heling in burn wounds treated with ethyl Linoleate alone or in combination with selected topical antibacterial agents. Ann Surg. 1975;182(5):562.

68. Sharma RK. Phytosterols: wide-spectrum antibacterial agents. Bioorg Chem 1993;21(1):49-60.

69. Devi S, Joseph J, Rajkumar J. In silico approach of antibacterial compounds from mangrove-Avicennia Marina through docking analysis. Biomed Res. 2015;26(4):50

70. Sivaraj C, Reddy BM, Rao PK. Selective dehydrogenation of cyclohexanol to cyclohexanone on cu ZnO al 203 catalysts. Appl Catal. 1988;45(1):L11-4.

71. Wang Y, Wang H, Jin Y, Bu C, Cheng J, Zhao L, et al. Assessment of the contact toxicity of methyl palmitate on Tetranychus viennensis (Acari: Tetranychidae). J Econ Entomol. 2010;103(4):1372-7.

72. Amin E, Radwan MM, El-Hawary SS, Fathy MM, Mohammed R, Becnel JJ, et al. Potent insecticidal secondary metabolites from the medicinal plant Acanthus montanus. Rec Nat Prod. 2012;6:301-5.

73. Tisdale WH, Bake LS. Combined fungicidal and insecticidal spray materials. In: Google patents; 1936.

74. Yan H, Feng R, Chen L, Chen A, Li G, Zhang X: Isolation, identification and insecticidal activities of six terpenoids in Sabina vulgaris. 2007.

75. Chogo J, Crank G. Chemical composition and biological activity of the Tanzanian plant Ocimum Suave. J Nat Prod. 1981;44(3):308-11.

\section{Submit your next manuscript to BioMed Central and we will help you at every step:}

- We accept pre-submission inquiries

- Our selector tool helps you to find the most relevant journal

- We provide round the clock customer support

- Convenient online submission

- Thorough peer review

- Inclusion in PubMed and all major indexing services

- Maximum visibility for your research

Submit your manuscript at www.biomedcentral.com/submit

) Biomed Central 